\title{
Responses of surface ozone air quality to anthropogenic nitrogen deposition in the Northern Hemisphere
}

\author{
Yuanhong Zhao ${ }^{1}$, Lin Zhang ${ }^{1}$, Amos P. K. Tai ${ }^{2}$, Youfan Chen ${ }^{1}$, and Yuepeng Pan ${ }^{3}$ \\ ${ }^{1}$ Laboratory for Climate and Ocean-Atmosphere Studies, Department of Atmospheric and Oceanic Sciences, School of \\ Physics, Peking University, Beijing 100871, China \\ ${ }^{2}$ Earth System Science Programme and Graduate Division of Earth and Atmospheric Sciences, Faculty of Science, The \\ Chinese University of Hong Kong, Hong Kong SAR, China \\ ${ }^{3}$ State Key Laboratory of Atmospheric Boundary Layer Physics and Atmospheric Chemistry (LAPC), Institute of \\ Atmospheric Physics, Chinese Academy of Sciences, Beijing 100029, China \\ Correspondence to: Lin Zhang (zhanglg@pku.edu.cn)
}

Received: 16 March 2017 - Discussion started: 11 April 2017

Revised: 12 July 2017 - Accepted: 21 July 2017 - Published: 21 August 2017

\begin{abstract}
Human activities have substantially increased atmospheric deposition of reactive nitrogen to the Earth's surface, inducing unintentional effects on ecosystems with complex environmental and climate consequences. One consequence remaining unexplored is how surface air quality might respond to the enhanced nitrogen deposition through surface-atmosphere exchange. Here we combine a chemical transport model (GEOS-Chem) and a global land model (Community Land Model, CLM) to address this issue with a focus on ozone pollution in the Northern Hemisphere. We consider three processes that are important for surface ozone and can be perturbed by the addition of atmospheric deposited nitrogen - namely, emissions of biogenic volatile organic compounds (VOCs), ozone dry deposition, and soil nitrogen oxide $\left(\mathrm{NO}_{x}\right)$ emissions. We find that present-day anthropogenic nitrogen deposition $\left(65 \mathrm{Tg} \mathrm{N}^{-1}\right.$ to the land), through enhancing plant growth (represented as increases in vegetation leaf area index, LAI, in the model), could increase surface ozone from increased biogenic VOC emissions (e.g., a $6.6 \mathrm{Tg}$ increase in isoprene emission), but it could also decrease ozone due to higher ozone dry deposition velocities (up to $0.02-0.04 \mathrm{~cm} \mathrm{~s}^{-1}$ increases). Meanwhile, deposited anthropogenic nitrogen to soil enhances soil $\mathrm{NO}_{x}$ emissions. The overall effect on summer mean surface ozone concentrations shows general increases over the globe (up to 1.5$2.3 \mathrm{ppbv}$ over the western US and South Asia), except for some regions with high anthropogenic $\mathrm{NO}_{x}$ emissions $(0.5-$ 1.0 ppbv decreases over the eastern US, western Europe, and
\end{abstract}

North China). We compare the surface ozone changes with those driven by the past 20-year climate and historical land use changes. We find that the impacts from anthropogenic nitrogen deposition can be comparable to the climate- and land-use-driven surface ozone changes at regional scales and partly offset the surface ozone reductions due to land use changes reported in previous studies. Our study emphasizes the complexity of biosphere-atmosphere interactions, which can have important implications for future air quality prediction.

\section{Introduction}

Reactive nitrogen, in the forms of reduced $\left(\mathrm{NH}_{x}\right)$ and oxidized nitrogen $\left(\mathrm{NO}_{y}\right)$, is an essential nutrient to the biosphere. Without human influence, reactive nitrogen is mainly fixed from inert nitrogen gas $\left(\mathrm{N}_{2}\right)$ through natural biological fixation, lightning, and wildfires (Galloway et al., 2004; Fowler et al., 2013). Human activities such as urbanization, industrialization, and agricultural development have led to the emission of large amounts of reactive nitrogen in the forms of nitrogen oxides $\left(\mathrm{NO}_{x}=\mathrm{NO}+\mathrm{NO}_{2}\right)$ and ammonia $\left(\mathrm{NH}_{3}\right)$ since the preindustrial period. Their removal via atmospheric deposition has increased by more than a factor of 3 from the preindustrial era to the early 2000s and has become an important source of reactive nitrogen to terrestrial 
and oceanic ecosystems (Galloway et al., 2004; Liu et al., 2013; Zhao et al., 2017).

Assessing the consequences of atmospheric nitrogen deposition requires a deep understanding of the interactions and feedbacks within different components of the Earth system including the biosphere and the atmosphere. There is evidence that enhanced atmospheric nitrogen deposition has led to negative effects such as soil acidification (Stevens et al., 2009; Lu et al., 2014), eutrophication (Rodríguez et al., 2006), and loss of biomass diversity (Baron et al., 2014). Atmospheric nitrogen deposition has also been shown to increase carbon storage in terrestrial and oceanic ecosystems, but the resulting climate benefits can be largely offset by increased emissions of nitrous oxide $\left(\mathrm{N}_{2} \mathrm{O}\right)$, a major greenhouse gas, as a byproduct of enhanced microbial nitrification and denitrification in soils (Duce et al., 2008; Zaehle et al., 2011; Bala et al., 2013). Previous studies mainly focused on the land-atmosphere exchange of long-lived greenhouse gases including $\mathrm{CO}_{2}, \mathrm{~N}_{2} \mathrm{O}$, and $\mathrm{CH}_{4}$ (Liu et al., 2009; Zaehle et al., 2011) and their effects on climate. Very few studies have explored how ecosystem-mediated feedbacks through atmospheric chemistry influence air quality. Here we will present such a study that investigates how human-induced atmospheric nitrogen deposition may affect atmospheric composition and air quality via modifying ecosystem structure in terms of foliage density, with a focus on surface ozone pollution.

Near-surface ozone is a harmful air pollutant that results in detrimental effects on human health and vegetation (Bates, 2005; Jerrett et al., 2009; Avnery et al., 2011). It is mainly formed in the troposphere by photochemical oxidation of carbon monoxide (CO) and volatile organic compounds (VOCs) in the presence of $\mathrm{NO}_{x}$. Tropospheric ozone burden has more than doubled since preindustrial times, mainly driven by rising anthropogenic emissions of ozone precursors $\left(\mathrm{NO}_{x}, \mathrm{CO}\right.$, and VOCs) and the recent equatorward shift of emission patterns (Young et al., 2013; Zhang et al., 2016). Ozone impact on plant growth is mainly affected through the plants' stomatal uptake and has been shown to severely damage forest, grassland and agricultural productivity (Ainsworth et al., 2012). Ozone damage impedes various foliage physiological functions, including photosynthesis and stomatal conductance, with ramifications not only for ecosystem health but also for the climate (Fowler et al., 2009; Matyssek et al., 2010; Yue et al., 2014, 2017; Sadiq et al., 2017). Major crops such as wheat, maize, rice, and soybean are also sensitive to surface ozone pollution, leading to concerns for global food security (Mills et al., 2007). Recent studies estimated that about $79-121 \mathrm{Tg}$ of crop production was reduced due to ozone pollution in year 2000 alone (Avnery et al., 2011), and future ozone damage on crops would lead to a $3.6 \%$ loss in total crop production under the Intergovernmental Panel on Climate Change (IPCC) RCP8.5 emission scenario (Tai et al., 2014).
The terrestrial biosphere can in turn affect surface ozone levels through surface-atmosphere exchange processes, including biogenic VOC emissions, soil $\mathrm{NO}_{x}$ emissions, and ozone dry deposition loss (Heald and Geddes, 2016). A number of studies have investigated how surface air quality may respond to perturbations of these processes driven by historical land use change (Fu and Tai, 2015; Val Martin et al., 2015; Fu et al., 2016; Heald and Geddes, 2016) and climate change (Fu and Tai, 2015; Fu et al., 2016). Atmospheric nitrogen deposition, by enhancing plant growth and soil mineral nitrogen content, is thus expected to modulate the production and loss of surface ozone. In this study, we build an asynchronously coupled modeling system using the GEOSChem global atmospheric chemistry model and the Community Land Model (CLM) to quantify the responses of surface ozone air quality to nitrogen deposition since preindustrial times via atmosphere-ecosystem exchange. We examine the individual processes that can be perturbed by nitrogen deposition and can then affect surface ozone concentrations, including biogenic VOC emissions, soil $\mathrm{NO}_{x}$ emissions, and ozone dry deposition. To evaluate the relative importance of nitrogen deposition, we also estimate the surface ozone changes driven by historical climate and land use changes which have been better constrained in recent studies as described above.

\section{Model description}

We combine a chemical transport model (GEOS-Chem) and a global land model (CLM) to investigate to interactions between nitrogen deposition and surface air quality. The interacting processes are given in the schematic diagram in Fig. 1 as will be discussed below. Asynchronous coupling of the two models allows us to examine individual processes. We describe in this section the two models, the asynchronously coupled framework, and our model simulations.

\subsection{The GEOS-Chem chemical transport model}

We use the GEOS-Chem global chemical transport model (v9-02; http://www.geos-chem.org) to characterize the contribution of anthropogenic sources to nitrogen deposition and responses of surface ozone to changes in vegetation density (as represented by the leaf area index, LAI) and soil $\mathrm{NO}_{x}$ emissions as will be provided by CLM. GEOS-Chem is driven by the MERRA (Modern Era Retrospective-analysis for Research and Applications) assimilated meteorological data from the NASA Global Modeling and Assimilation Office (GMAO). We run the GEOS-Chem model at a global horizontal resolution of $2^{\circ}$ latitude by $2.5^{\circ}$ longitude and 47 levels in the vertical.

The GEOS-Chem model has been applied in a number of studies to simulate atmospheric nitrogen deposition (Zhang et al., 2012; Ellis et al., 2013; Zhao et al., 2015, 2017), 


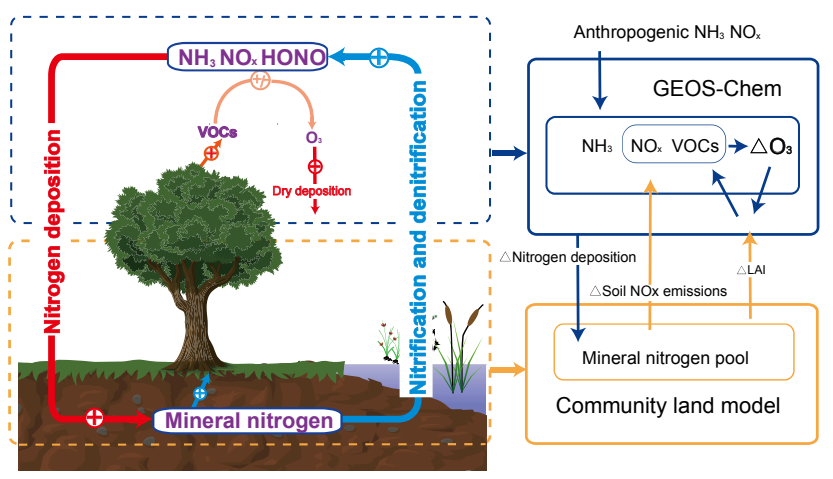

Figure 1. The schematic diagram and flowchart of the landatmosphere asynchronously coupled system for the study.

surface ozone air quality (Zhang et al., 2011, 2014; Fu et al., 2015), and recently impacts of land use changes on atmospheric composition through biosphere-atmosphere exchange processes (Fu and Tai, 2015; Fu et al., 2016; Geddes et al., 2016; Heald and Geddes, 2016). It includes a detailed simulation of tropospheric $\mathrm{NO}_{x}-\mathrm{VOC}-\mathrm{O}_{3}$-aerosol chemistry (Park et al., 2004; Mao et al., 2010). The model wet deposition scheme including scavenging in convective updraft and large-scale precipitation is described by Liu et al. (2001) for aerosols and by Mari et al. (2000) and Amos et al. (2012) for soluble gases. The dry deposition parameterization for gases and aerosols follows a standard bigleaf resistance-in-series model (Wesely, 1989; Zhang et al., 2001). Dry deposition velocities are calculated as a combination of aerodynamic resistance, boundary layer resistance, and surface resistance.

We use the global anthropogenic emissions from the EDGAR v4.2 (the Emission Database for Global Atmospheric Research version 4.2) emission inventory (EDGAR, 2015), overwritten by regional inventories including EMEP (the European Monitoring and Evaluation Programme) over Europe (Vestreng and Klein, 2002) and REAS v2 (the Regional Emission inventory in ASia version 2) over East Asia (Kurokawa et al., 2013) with the $\mathrm{NH}_{3}$ emission seasonality from Zhao et al. (2015). Natural sources include emissions from biomass burning, lightning, soil, and the biosphere. Here biomass burning emissions are from the GFED v3 (the Global Fire Emissions Database version 3) emission inventory (van der Werf et al., 2010). Lightning $\mathrm{NO}_{x}$ emissions, as described by Sauvage et al. (2007) and Murray et al. (2012), are calculated using the cloud top height parameterization of Price and Rind (1992) and vertical distribution of Pickering et al. (1998) and are further spatially redistributed to match satellite observations of lightning flashes.

We implement the following modifications so that GEOSChem and CLM harmonize land surface properties for simulating surface-atmosphere exchange processes including biogenic VOC emissions, soil $\mathrm{NO}_{x}$ emissions, and dry deposition. We follow Geddes et al. (2016) and use the 16 plant functional types (PFTs) from CLM in the GEOS-Chem land module. The biogenic VOC emissions in GEOS-Chem are calculated using the Model of Emissions of Gases and Aerosols from Nature version 2.1 (MEGAN v2.1) algorithm based on emission factors of the 16 PFTs and activity factors accounting for emission responses to soil and meteorological conditions, leaf age, and LAI (Guenther et al., 2012). The original above-soil $\mathrm{NO}_{x}$ emissions in GEOS-Chem are based on the empirical parameterization of Hudman et al. (2012). In this study, we calculate the above-soil $\mathrm{NO}_{x}$ emissions in CLM (with improvements as described below and in the Appendix) and archive the values hourly for input to GEOSChem. The canopy reduction and emission pulsing scalars from Hudman et al. (2012) are applied to estimate the abovecanopy $\mathrm{NO}_{x}$ emissions. Furthermore, we have mapped the 16 CLM PFTs to the deposition surface types of Wesely (1989) following Geddes et al. (2016) to improve the consistency in dry deposition calculation.

\subsection{The Community Land Model}

We use the Community Land Model (CLM v4.5; Oleson et al., 2013), the land component of the Community Earth System Model (CESM), to simulate responses of LAI and soil $\mathrm{NO}_{x}$ emissions to enhanced atmospheric nitrogen deposition from anthropogenic sources. We run the CLM model at the resolution of $2.5^{\circ}$ latitude by $1.9^{\circ}$ longitude, driven by the CRU-NCEP (Climatic Research Unit-National Centers for Environmental Prediction) climate forcing dataset (CRUNCEP, 2015), which combines the CRU TS3.2 monthly data and the NCEP 6-hour reanalysis data with additional data over oceans, lakes, and Antarctica from Qian et al. (2006). Other model inputs such as initial conditions, surface parameters, and physiological constants are from the CESM input data repository (CESM, 2015).

The CLM model in its active biogeochemistry (BGC) mode simulates detailed terrestrial biogeophysical and biogeochemical processes such as surface energy fluxes, hydrology, and biogeochemical cycles as described by Oleson et al. (2013). Each grid cell is divided into five land units including vegetation, lake, urban, glacier, and crop. The vegetation-covered areas are further characterized by 16 PFTs, which are derived from MODIS observations to represent the present-day condition (Lawrence and Chase, 2007). The CLM v4.5 model includes a vertically resolved soil biogeochemistry scheme that considers vertical transport of soil carbon and nitrogen (Koven et al., 2013). In the model, nitrogen input to the soil mineral nitrogen pool is through atmospheric deposition and biological fixation. The mineral nitrogen can be transformed to organic nitrogen by plant uptake and immobilization or can leave the ecosystem through denitrification, leaching, and other loss processes (Oleson et al., 2013). 
CLM v4.5 also includes the Century nitrogen model of del Grosso et al. (2000), which divides the soil mineral nitrogen into $\mathrm{NH}_{4}^{+}$and $\mathrm{NO}_{3}^{-}$, and calculates nitrification and denitrification rates accordingly. It allows the model to calculate the $\mathrm{N}_{2} \mathrm{O}$ emission fluxes associated with nitrification and denitrification (del Grosso et al., 2000). We further add in the model a parameterization of soil $\mathrm{NO}_{x}$ emissions based on the $\mathrm{NO}_{x}$ and $\mathrm{N}_{2} \mathrm{O}$ ratio as described in the Appendix. We have implemented some modifications to CLM4.5 so that the simulated soil $\mathrm{NO}_{x}$ emissions are consistent with the GEOSChem scheme (Appendix, Fig. S1 in the Supplement). These modifications also slightly correct the large CLM overestimations in the vegetation LAI (Dahlin et al., 2015; Duarte et al., 2017) (Fig. S2) mainly due to reduced nitrogen uptake by plant in our model.

For each CLM simulation in this study, we spin up the model for a thousand years for the soil nitrogen content to reach equilibrium using the meteorological data of 20062010 and present-day or preindustrial nitrogen deposition fluxes. We use the last-five-years result for analysis. The CLM simulations use prescribed, constant PFT distributions and soil types. We will investigate the influences of land use change on surface ozone by a separate GEOS-Chem simulation as described below. We conduct these idealized nearequilibrium CLM simulations instead of transient simulations because terrestrial ecosystems respond slowly to the environment changes (Jones et al., 2009). Here we aim to provide a first quantitative analysis of surface ozone responses, and the near-equilibrium simulations present an estimate of the long-term influence that might occur in the future (Bala et al., 2013).

\subsection{Asynchronous coupling and model experiments}

As illustrated in Fig. 1, reactive nitrogen emitted to the atmosphere by human activities, mainly as $\mathrm{NH}_{3}$ and $\mathrm{NO}_{x}$, will return to the land surface through wet and dry deposition processes. This deposited nitrogen will add into the soil mineral nitrogen content and will further enhance plant growth as well as nitrification and denitrification in the nitrogen-limited areas. The influences on surface ozone occur via three main processes: increasing biogenic VOC emissions while accelerating ozone dry deposition due to plant growth (as represented by increases in LAI in this study) and perturbing soil $\mathrm{NO}_{x}$ emissions from the enhanced soil mineral nitrogen pool. Besides $\mathrm{NO}_{x}$, soil mineral nitrogen can also release to the atmosphere as nitrous acid (HONO), which influences atmospheric oxidative capacity (Su et al., 2011). Here we do not consider the influence through HONO due to a lack of its emission parameterization and chemistry simulation in both global models used in this study.

We set up an asynchronously coupled system using GEOS-Chem and CLM to investigate the influences of nitrogen deposition on surface ozone from the individual processes and the overall effects. We first calculate the global nitrogen deposition fluxes using the GEOS-Chem model averaged for the years 2006-2010. The simulated nitrogen deposition fluxes are then fed into CLM to compute LAI and soil $\mathrm{NO}_{x}$ emissions. To quantify the perturbations induced by human activities, two sets of GEOS-Chem and CLM simulations are conducted with all anthropogenic emissions turned on or off, representing the consequences of nitrogen deposition at the present-day vs. preindustrial conditions. Anthropogenic contributions are calculated as the differences between the two simulations. Finally, the CLM-simulated LAI and soil $\mathrm{NO}_{x}$ are returned to GEOS-Chem, which completes the land-atmosphere coupling and allows us to examine the impacts of nitrogen deposition on surface ozone concentrations.

Table 1 summarizes the GEOS-Chem simulations as the final step in this study. These simulations are conducted with all anthropogenic emissions but with different LAI values and soil $\mathrm{NO}_{x}$ emissions simulated by CLM. The simulation for the present-day condition (Run_all) applies the CLM-simulated present-day LAI and soil $\mathrm{NO}_{x}$ emissions. Its differences from the simulation with natural conditions (Run_nat) estimate the overall effect of anthropogenic nitrogen deposition on surface ozone. By considering the individual processes separately (Run_VOCs, Run_soilnox, and Run_drydep), simulated ozone differences with Run_nat represent their separated effects.

To evaluate the importance of nitrogen deposition, we put our analyses in the context of comparisons with surface ozone changes driven by historical climate and land use changes. As listed in Table 2, we conduct the GEOSChem simulations by using the 1986-1990 MERRA fields (for comparison with the 2006-2010 fields) or the preindustrial land use data (1860 vs. the present-day condition for 2000), generally following the previous work of Fu and Tai (2015) and Heald and Geddes (2016). The impacts of climate change on wildfire emissions (Yue et al., 2015) are not considered here.

\section{Global emissions and deposition of reactive nitrogen}

We first evaluate the model simulation of present-day atmospheric nitrogen deposition at the global scale. Figure 2 shows the spatial distribution of annual total $\mathrm{NH}_{3}$ and $\mathrm{NO}_{x}$ emissions and the percentage contribution from anthropogenic sources averaged over the years 2006-2010. Global total $\mathrm{NH}_{3}$ and $\mathrm{NO}_{x}$ emissions are 62 and $54 \mathrm{Tg} \mathrm{N} \mathrm{a}^{-1}$, of which $69 \%\left(43 \mathrm{Tg} \mathrm{N} \mathrm{a}^{-1}\right)$ and $61 \%\left(33 \mathrm{Tg} \mathrm{N} \mathrm{a}^{-1}\right)$ are from anthropogenic sources. Natural emissions include those from lightning $\left(4.8 \mathrm{Tg} \mathrm{N} \mathrm{a}^{-1}\right.$ as $\left.\mathrm{NO}_{x}\right)$, biomass burning (4.9 Tg N a ${ }^{-1}$ as $\mathrm{NH}_{3}$ and $6.8 \mathrm{Tg} \mathrm{Na}^{-1}$ as $\mathrm{NO}_{x}$ ), soil (5.6 $\mathrm{Tg} \mathrm{N} \mathrm{a}^{-1}$ as $\mathrm{NH}_{3}$ and $9.4 \mathrm{Tg} \mathrm{N} \mathrm{a}^{-1}$ as $\mathrm{NO}_{x}$ ), and ocean $\left(8.6 \mathrm{Tg} \mathrm{N}\right.$ as $\mathrm{NH}_{3}$ ). About $96 \%$ of the anthropogenic emissions are in the Northern Hemisphere. We will thus focus our analyses on the Northern Hemisphere in the study. 
Table 1. GEOS-Chem simulations to quantify surface ozone response to nitrogen deposition from each process and the net effect*

\begin{tabular}{llllll}
\hline & Run_all & Run_VOCs & Run_soilnox & Run_drydep & Run_nat \\
\hline Biogenic VOCs & All & All & Nat & Nat & Nat \\
Soil NO $\mathrm{NO}_{x}$ & All & Nat & All & Nat & Nat \\
Dry deposition & All & Nat & Nat & All & Nat \\
\hline
\end{tabular}

* In the table, "All" represents the use of CLM outputs simulated with the present-day atmospheric nitrogen deposition and "Nat" represents the use of CLM outputs with natural nitrogen deposition alone. All GEOS-Chem simulations listed in the table are conducted with present-day anthropogenic and natural emissions turned on.
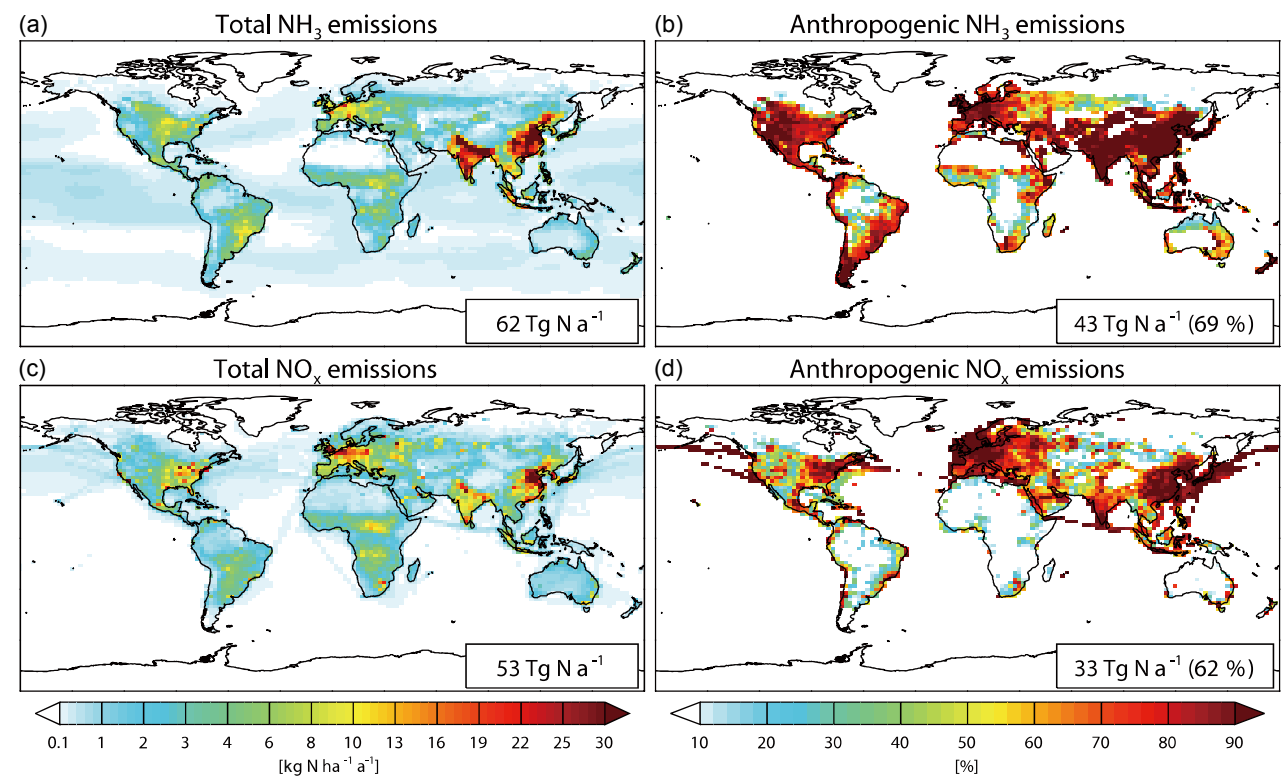

Figure 2. Spatial distribution of total $\mathrm{NH}_{3}(\mathbf{a})$ and $\mathrm{NO}_{x}$ emissions (c) and percentage contribution from anthropogenic sources (b, d) averaged for 2006-2010. Annual global total values are shown inset.

Table 2. GEOS-Chem simulations with the input data time listed to quantify surface ozone changes driven by historical climate and land use changes.

\begin{tabular}{lrrr}
\hline & Run_std & Run_met & Run_land \\
\hline Land use & 2000 & 2000 & 1860 \\
Meteorology & $2006-2010$ & $1986-1990$ & $2006-2010$ \\
\hline
\end{tabular}

East Asia (especially eastern China and India), Europe, and North America are the major emitting regions with high ratios of anthropogenic contribution. Over the three regions, total reactive nitrogen emissions reach more than 100,60 , and $50 \mathrm{~kg} \mathrm{Nha}^{-1} \mathrm{a}^{-1}$, and about $75-90 \%$ of them are from anthropogenic sources. Most reactive nitrogen is emitted as $\mathrm{NH}_{3}$ in China and India (62\% in China and $71 \%$ in India), while $\mathrm{NO}_{x}$ is more abundant in Europe and North America (61\% in Europe and $62 \%$ in North America), reflecting their different levels of agricultural activities.

Figure 3 shows GEOS-Chem-simulated spatial distributions of annual total (reduced + oxidized) nitrogen de- position fluxes and percentage contributions from anthropogenic emissions averaged over 2006-2010. Global total nitrogen deposition is simulated to be $114 \mathrm{Tg} \mathrm{N} \mathrm{a}^{-1}$, with $59 \%$ $\left(67 \mathrm{Tg} \mathrm{Na}^{-1}\right)$ from wet deposition and $41 \%$ from dry deposition. A total of $65 \operatorname{Tg} \mathrm{N}\left(38 \mathrm{Tg} \mathrm{N}\right.$ as $\mathrm{NH}_{x}$ and $27 \mathrm{Tg} \mathrm{N}$ as $\mathrm{NO}_{y}$ ) is deposited to the continents, and the remaining $49 \mathrm{Tg} \mathrm{N}$ is deposited to the ocean. Our results are comparable with previous global model estimates of Dentener et al. (2006) and, more recently, Lamarque et al. (2013) and Vet et al. (2014). Using an ensemble of 21 global chemical transport models, Vet et al. (2014) estimated a global total nitrogen deposition of $106 \mathrm{Tg} \mathrm{N} \mathrm{a}^{-1}$, with $55.6 \%$ deposited over the continental non-coastal areas for 2001. Deposition patterns of reactive nitrogen show a similar spatial distribution to their emissions due to the short lifetimes. Deposition fluxes reach more than $30 \mathrm{~kg} \mathrm{Nha}^{-1} \mathrm{a}^{-1}$ in Asia (in particular China and India) and $10 \mathrm{~kg} \mathrm{Nha}^{-1} \mathrm{a}^{-1}$ in Europe and North America, in agreement with the results of Vet et al. (2014). Anthropogenic emissions contribute $71 \%$ of total nitrogen deposition to the land on a global scale. The anthropogenic contributions are greater than $50 \%$ in the Northern 

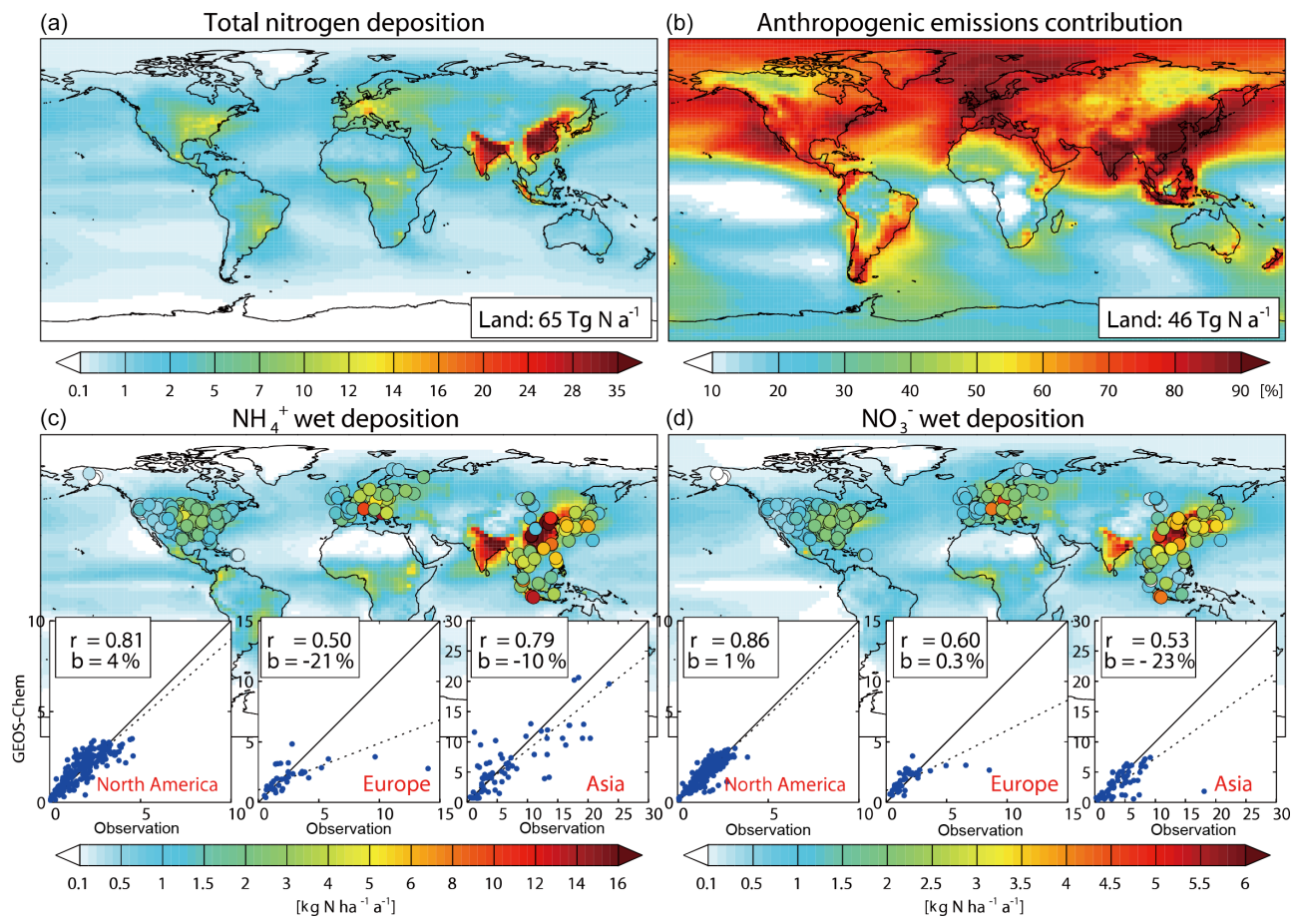

Figure 3. Top panels show total nitrogen deposition fluxes (left) and contributions from anthropogenic sources estimated as percentage changes in the GEOS-Chem simulation with all anthropogenic emissions turned off relative to the simulation with anthropogenic emissions turned on (right). Annual total deposition values to land are shown inset. Bottom panels compare the simulated $\mathrm{NH}_{4}^{+}$(left) and $\mathrm{NO}_{3}^{-}$ (right) wet deposition fluxes with an ensemble of surface measurements over North America, Europe, and Asia as described in the text. The comparison scatterplots are overplotted with correlation coefficients $(r)$ and normalized mean biases $(b)$ also shown inset.

Hemisphere and reach more than $70 \%$ in North America, $80 \%$ in western Europe, and $90 \%$ in East Asia.

We compare our simulation with $\mathrm{NH}_{4}^{+}$and $\mathrm{NO}_{3}^{-}$wet deposition flux measurements available for the same period of 2006-2010, including measurements from the Acid Deposition Monitoring Network in East Asia (EANET, 2015) and ten surface monitoring sites in North China from Pan et al. (2012), the European Monitoring and Evaluation Programme (EMEP, 2015) in Europe, and the National Atmospheric Deposition Program (NADP, 2015) in North America. There is a lack of direct measurements of dry deposition fluxes (Vet et al., 2014); however, previous studies have evaluated the GEOS-Chem-simulated nitrogen dry deposition fluxes over the US and China using concentration measurements from surface sites and satellites, and they showed good agreement (Zhang et al., 2012; Zhao et al., 2017).

Comparisons of measured vs. simulated wet deposition fluxes over North America, Europe, and Asia are shown in Fig. 3, with the correlation coefficient $(r)$ and normalized mean bias $\left(\mathrm{NMB}=\sum_{i=1}^{N}\left(M_{i}-O_{i}\right) / \sum_{i=1}^{N} O_{i}\right)$ between the observed $(O)$ and modeled $(M)$ values over the $N$ sites computed. Over the three high-nitrogen-depositing continents, comparisons generally show high correlation coefficients $(r=0.50-0.86)$ and low biases for both $\mathrm{NH}_{4}^{+}$and $\mathrm{NO}_{3}^{-}$wet deposition, except for biases of $-21 \%$ for $\mathrm{NH}_{4}^{+}$wet deposition over Europe and $-23 \%$ for $\mathrm{NO}_{3}^{-}$over East Asia. The high negative biases are likely due to the difficulty of simulating very high deposition fluxes measured at urban sites as suggested by Zhao et al. (2017) that evaluated GEOS-Chemestimated nitrogen deposition over China at a finer horizontal resolution. Globally, the model is able to capture the magnitudes and spatial distribution of observations with high correlation coefficients of 0.86 for $\mathrm{NH}_{4}^{+}$and 0.70 for $\mathrm{NO}_{3}^{-}$and small biases of $-5 \%$ for $\mathrm{NH}_{4}^{+}$and $-8 \%$ for $\mathrm{NO}_{3}^{-}$, providing credence to the model simulation of present-day atmospheric nitrogen deposition.

\section{Impact of anthropogenic nitrogen deposition on land properties}

\subsection{Changes in vegetation LAI and subsequent responses}

We discuss in this section the changes in ecosystem structure in terms of foliage density driven by present-day anthropogenic nitrogen deposition as simulated by CLM. Figure 4 shows the simulated present-day spatial distribution of vegetation LAI and the perturbations due to anthropogenic nitrogen deposition calculated as the differences between 

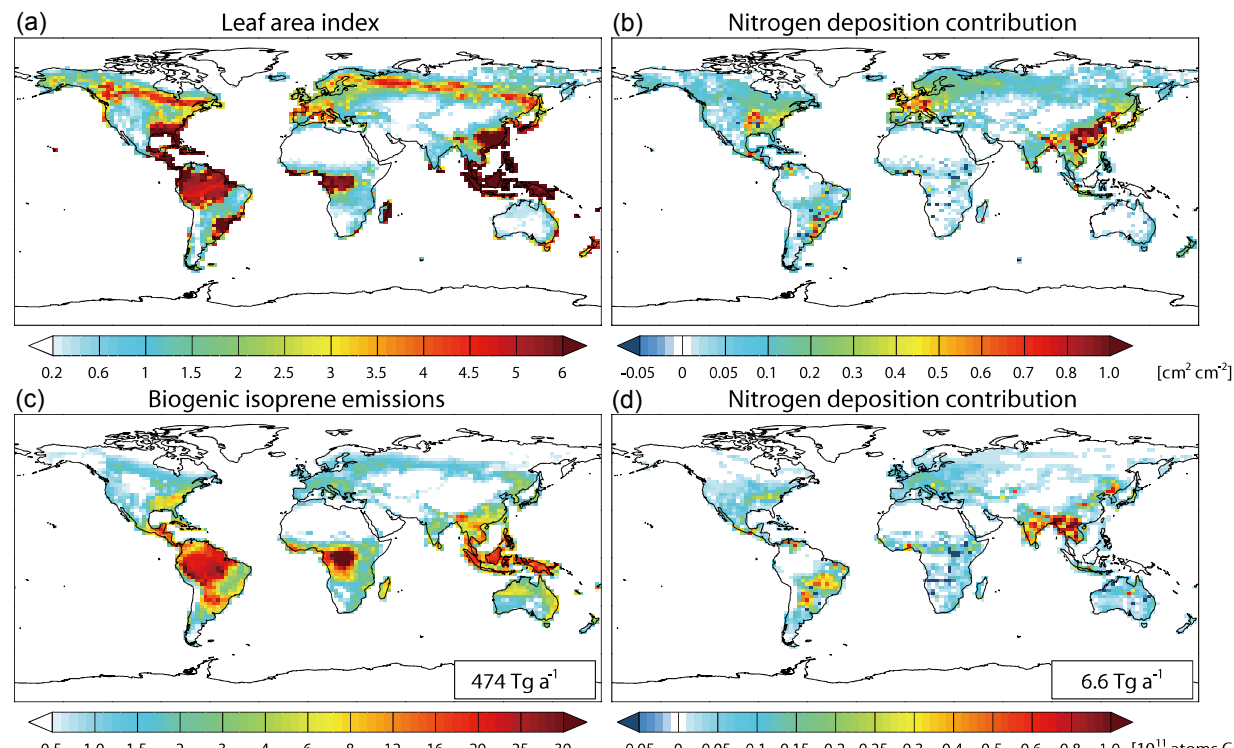

(d) Nitrogen deposition contribution

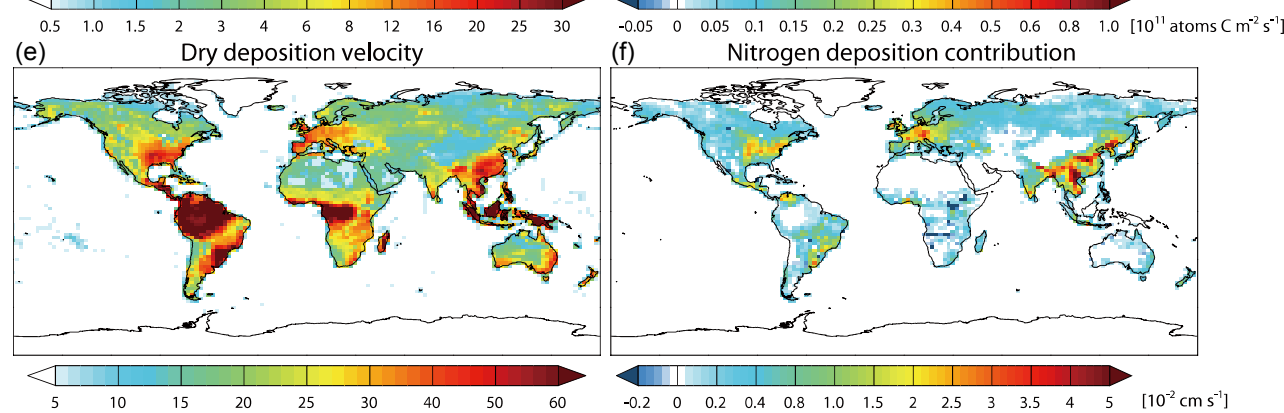

Figure 4. Leaf area index (a, b), biogenic isoprene emission (c, $\mathbf{d}$ with annual total emissions shown inset), and dry deposition velocity for ozone (e, f) as simulated by the asynchronously coupled modeling system. Panels (a), (c), and (e) represent the present-day conditions, and panels (b), (d), and (f) show perturbations as could be driven by human-induced atmospheric nitrogen deposition.

CLM simulations forced by total vs. natural-only nitrogen deposition. Vegetation growth is limited by nitrogen supply over most of the globe. We find that anthropogenic nitrogen deposition enhances global net primary production (NPP) by $3.7 \mathrm{Pg} \mathrm{Ca}^{-1}$, increasing LAI over those nitrogenlimited areas. Our estimated global NPP increase is consistent with Bala et al. (2013), who used an earlier version of CLM (CLM4.0) and showed that doubling (quadrupling) nitrogen deposition from the preindustrial level would increase global NPP by 2.6 (6.8) $\mathrm{Pg} \mathrm{Ca}^{-1}$. As shown in Fig. 4, LAI values increase by $0.1-0.7,0.1-0.9$, and greater than $1.0 \mathrm{~cm}^{2} \mathrm{~cm}^{-2}$ due to anthropogenic nitrogen deposition over the three hotspots of nitrogen deposition - North America, Europe, and East Asia, respectively. The high increases over southeastern China may also partly reflect the LAI overestimation in CLM (Supplement Fig. S2); we will discuss the associated uncertainties in the next section.

Enhancement in LAI can subsequently lead to higher biogenic VOC emissions and also higher ozone dry deposition velocities by lowering surface resistance. As shown in Fig. 4, GEOS-Chem simulates a global total isoprene emission of $474 \mathrm{Tg} \mathrm{a}^{-1}$ for the present-day condition, and anthropogenic nitrogen deposition contributes about $6.6 \mathrm{Tg}$ $\mathrm{a}^{-1}(1.4 \%)$ from the LAI enhancement. Isoprene emissions are more sensitive to LAI changes at lower LAI areas due to suppression of sunlight from dense leaves. Thus, emissions over southeastern China do not show large increases despite significant LAI enhancement $\left(0.8-1.0 \mathrm{~cm}^{2} \mathrm{~cm}^{-2}\right)$, while smaller LAI changes $\left(0.2-0.6 \mathrm{~cm}^{2} \mathrm{~cm}^{-2}\right)$ over regions such as India and southeastern Brazil lead to distinct increases in isoprene emissions up to $10-15 \%$. As for dry deposition, the deposition velocities for ozone tend to increase with increasing LAI. We estimate that anthropogenic nitrogen deposition increases ozone dry deposition velocity by about $0.02 \mathrm{~cm} \mathrm{~s}^{-1}(\sim 8 \%)$ over the eastern US and western Europe and $0.04 \mathrm{~cm} \mathrm{~s}^{-1}(10 \%)$ over eastern and southern Asia.

\subsection{Changes in soil $\mathrm{NO}_{x}$ emissions}

Figure 5 shows how addition of deposited anthropogenic nitrogen to the soil mineral nitrogen pool could perturb soil $\mathrm{NO}_{x}$ emissions. As described above, we calculate the abovesoil $\mathrm{NO}_{x}$ emissions in CLM using a scaling parameteriza- 


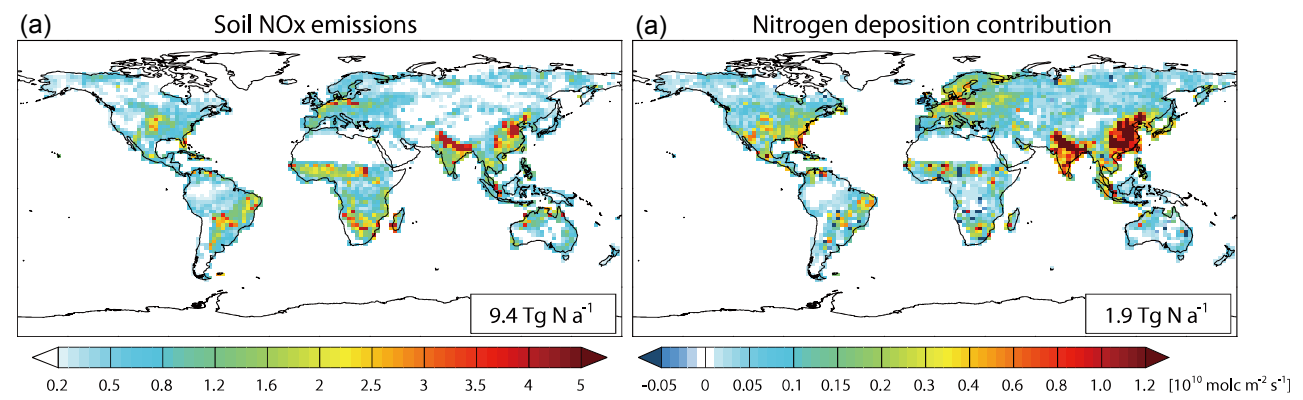

Figure 5. Present-day soil $\mathrm{NO}_{x}$ emissions (left) and contributions from anthropogenic nitrogen deposition (right). Annual totals are shown inset.

tion with respect to $\mathrm{N}_{2} \mathrm{O}$ emission fluxes associated with nitrification and denitrification. Our CLM model results estimate that anthropogenic nitrogen deposition contributes to global emissions of $45.4 \mathrm{Tg} \mathrm{N} \mathrm{a}^{-1}$ as $\mathrm{N}_{2}, 1.32 \mathrm{Tg} \mathrm{N}$ as $\mathrm{N}_{2} \mathrm{O}$, and $2.6 \mathrm{Tg} \mathrm{N}$ as $\mathrm{NO}_{x}$ above soil. Zaehle et al. (2011) previously estimated that global $\mathrm{N}_{2} \mathrm{O}$ emissions increased by $0.8 \mathrm{Tg} \mathrm{N} \mathrm{a}^{-1}$ from 1860 to 2005 due to atmospheric nitrogen deposition using transient simulations of a terrestrial land model. Our estimate $\left(1.32 \mathrm{Tg} \mathrm{N}-\mathrm{N}_{2} \mathrm{O}\right)$ is reasonably higher considering we use the near-equilibrium simulations.

We estimate the present-day global above-canopy $\mathrm{NO}_{x}$ emissions to be $9.4 \mathrm{Tg} \mathrm{Na}^{-1}$ (Fig. 5), and they are in good agreement with the results estimated by the GEOS-Chem soil $\mathrm{NO}_{x}$ scheme of Hudman et al. (2012) for the same period in terms of both the global magnitude $\left(9.3 \mathrm{Tg} \mathrm{N} \mathrm{a}^{-1}\right)$ and spatial distribution (Supplement Fig. S1). A total of $1.9 \mathrm{Tg} \mathrm{N} \mathrm{a}^{-1}$ of the above-canopy $\mathrm{NO}_{x}$ emissions are contributed by the addition of deposited anthropogenic nitrogen, and $46 \%$ of the increased emissions occur over China and India. As shown in Fig. 5, anthropogenic nitrogen deposition can lead to significant increases in the soil $\mathrm{NO}_{x}$ emissions especially in the Northern Hemisphere. These increases account for 30$70 \%$ of local soil $\mathrm{NO}_{x}$ emissions over regions of China, India, the US, and Europe. There is also a strong seasonality in the enhanced soil $\mathrm{NO}_{x}$ emissions since nitrification and denitrification rates are highly dependent on surface temperature. We find that $41 \%(0.77 \mathrm{Tg} \mathrm{N})$ of the emission enhancement occurs in June-July-August, and only $13 \%$ occurs in December-January-February.

\section{Responses of surface ozone pollution}

\subsection{Surface ozone concentration}

We now examine the changes in surface ozone air quality as driven by the overall effect of anthropogenic nitrogen deposition as well as the individual processes of dry deposition, biogenic VOC, and soil $\mathrm{NO}_{x}$ emissions. We use the metric of daytime (08:00-18:00 local time) mean surface ozone concentration. Figures 6 and 7 show the resulting sur- face ozone changes in the Northern Hemisphere averaged over summer (June-July-August) and spring (March-AprilMay), respectively. We find overall increases in the surface ozone concentration over the globe except for some regions with high $\mathrm{NO}_{x}$ emissions. In June-July-August, the mean surface ozone changes are generally within \pm 3 ppbv, with about $1 \mathrm{ppbv}$ increases over the southwestern US and northern Europe and with nearly 2 ppbv over India, north-central China, and northern African grassland, while about $0.5 \mathrm{ppbv}$ decreases in the eastern US, and 1 ppbv decreases over North China and western Europe. Similar patterns are found for spring (March-April-May) (Fig. 7), but changes are weaker than for summer.

The overall impacts of nitrogen deposition on surface ozone are buffered from their effects through individual processes. Figures 6 and 7 also show the separated effects from changes in dry deposition, biogenic VOC emissions, and soil $\mathrm{NO}_{x}$ emissions. Increases in vegetation LAI tend to increase surface ozone concentrations due to higher biogenic VOC emissions but are largely offset by increases in the ozone loss through higher dry deposition velocities. The net effects of two depend on the LAI values and the relative changes. For example, India as one of the regions with the largest relative changes in LAI shows higher ozone changes driven by biogenic VOC emissions than the decreases from dry deposition. Meanwhile, the ozone responses to soil $\mathrm{NO}_{x}$ emissions are nonlinear depending on whether the area is $\mathrm{NO}_{x}$ limited or $\mathrm{NO}_{x}$ saturated. As shown in Fig. 6f, soil $\mathrm{NO}_{x}$ emission enhancements generally increase summer mean surface ozone concentrations in the Northern Hemisphere except for North China, where anthropogenic $\mathrm{NO}_{x}$ emissions are particularly large and ozone production is limited by VOC emissions as reported in recent studies (Tang et al., 2012).

One of the largest uncertainties arises from the CLM overestimation of vegetation LAI (Supplement Fig. S2). To test this uncertainty, we have conducted another set of simulations in which the GEOS-Chem model simulations use observed LAI from the MODIS satellite instrument, and the CLM-simulated present-day vs. natural LAI enhancement ratios are applied to adjust MODIS LAI to examine the contribution of anthropogenic nitrogen deposition. The result- 
(a) Nitrogen deposition

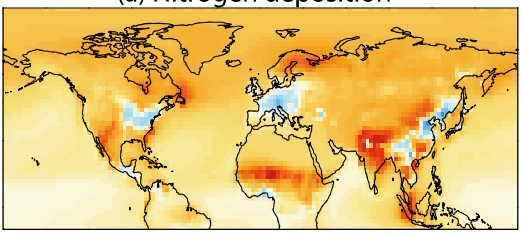

(d) Dry deposition (b) Climate change

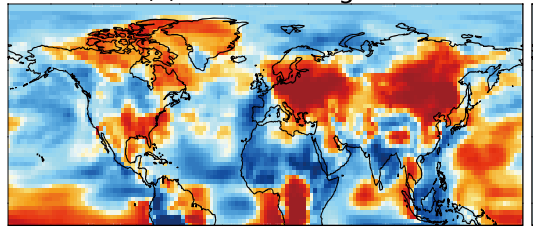

(e) Biogenic VOCs emissions (c) Land use change

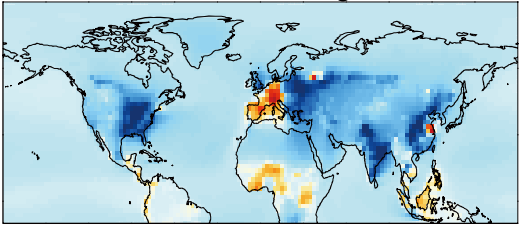

(f) Soil NOx emissions
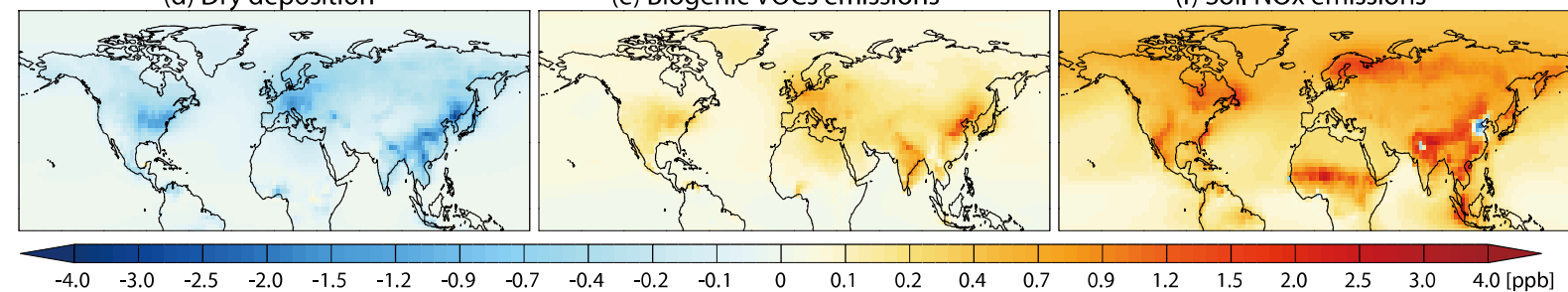

Figure 6. Changes in mean surface ozone concentration for June-July-August driven by anthropogenic nitrogen deposition (top-left panel), changes in climate (2006-2010 vs. 1986-1990; top-middle panel) and land use (present-day vs. 1860 conditions; top-right panel). Model simulations are described in the text. Bottom panels separate the anthropogenic-nitrogen-deposition-induced ozone changes into those due to three processes: changes in dry deposition velocity, biogenic VOC emissions, and soil $\mathrm{NO}_{x}$ emissions.

(a) Nitrogen deposition

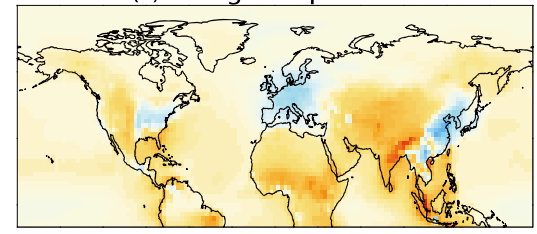

(d) Dry deposition (b) Climate change

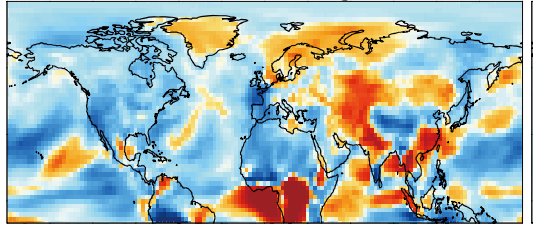

(e) Biogenic VOCs emissions (c) Land use change

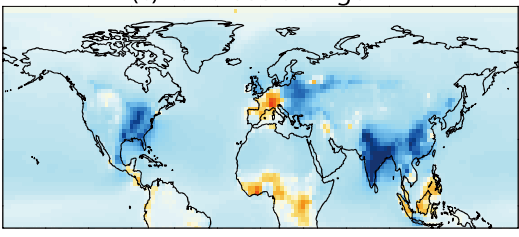

(f) Soil NOx emissions

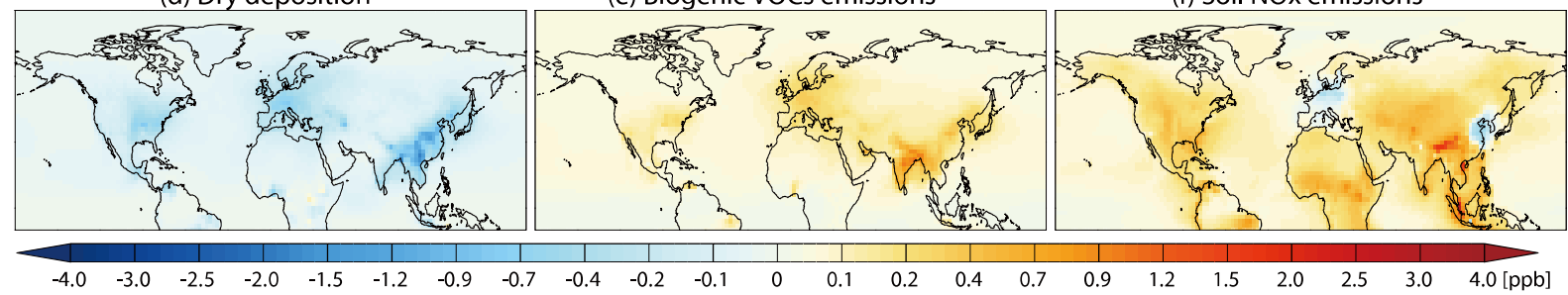

Figure 7. Same as Fig. 6 but for March-April-May.

ing impacts of anthropogenic nitrogen deposition on biogenic isoprene emissions, ozone dry deposition velocities, and summer mean surface ozone concentrations are shown in Supplement Fig. S3. Using adjusted MODIS LAI would lead to larger increases in biogenic isoprene emissions from anthropogenic nitrogen deposition (globally $8.2 \mathrm{Tg} \mathrm{a}^{-1}$ with the MODIS LAI vs. 5.6 $\mathrm{Tg} \mathrm{a}^{-1}$ with the CLM LAI for the year 2009) and weaker increases in dry deposition velocity. As for summer mean surface ozone, we find that the differences are minor over the globe except for southeastern China, where the largest LAI overestimate in CLM occurs. Changes in summer mean surface ozone due to anthropogenic nitrogen deposition are around 0.1-2.0 ppbv with the adjusted MODIS LAI but are overall negative (up to $-1.0 \mathrm{ppbv}$ ) with the CLM LAI over this region, reflecting the combined effect of enhanced biogenic VOC emissions and reduced ozone dry deposition loss with lower LAI.

\subsection{Comparisons with climate- and land-use-driven surface ozone changes}

We also show in Figs. 6 and 7 surface ozone changes driven by historical climate (1986-1990 vs. 2006-2010) and land use (1860 vs. 2000$)$ changes as simulated by the GEOSChem model. The changes for ozone dry deposition velocity, biogenic isoprene, and soil $\mathrm{NO}_{x}$ emissions are included in the Supplement (Fig. S4). Surface ozone changes from the 20-year climate change show a large spatial variability with more than $\pm 10 \mathrm{ppbv}$ concentration changes in both spring and summer. The large variations are mainly driven by changes in surface temperature and other meteorological variables as found in previous studies (Camalier et al., 2007; Jacob and Winner, 2009; Doherty et al., 2013). The large ozone concentration increases over northern Eurasia and Africa are associated with higher temperature in 2006- 
2010 relative to $1986-1990$, which leads to higher biogenic VOC emissions (Fig. S4) and stronger ozone photochemical production rates. Meanwhile, higher temperature decreases surface ozone over remote regions (ocean and deserts) due to stronger ozone loss and less PAN transported from source regions (Doherty et al., 2013). Part of the ozone differences are also associated with changes in ozone dry deposition velocities and soil $\mathrm{NO}_{x}$ emissions as driven by changes in temperature and planetary boundary layer height (Figs. S4 and S5).

The historical land use change has led to decreases in surface ozone concentrations up to 5-7 ppbv for the summer mean over most regions except for some areas in western Europe, North China, and central Africa where there are slight increases. These results are consistent with the recent work of Heald and Geddes (2016) that investigated the impacts of changes in land types and agricultural activities on surface air quality. The land-use-induced surface ozone changes are largely caused by a shift of forest trees with high biogenic emission factors to grasslands and croplands with low emission factors from 1860 to 2000 . This shift in land types has also led to changes in ozone dry deposition velocity by up to $10 \%$ due to the combined impacts of LAI changes, cropland expansion (enhancing ozone vegetation uptake), and deforestation (decreasing ozone dry deposition velocity; Heald and Geddes, 2016).

Compared with the impacts from climate change, surface ozone changes induced by anthropogenic nitrogen deposition ( \pm 3 ppbv) are smaller on a global scale but can be rather important at the local and regional scales. The anthropogenicnitrogen-deposition-induced ozone changes are usually $10 \%$ of those induced by climate change at low and middle latitudes but reach about $50 \%$ at high latitudes (e.g., Canada and northern Europe). These values are also comparable to impacts from land use changes over regions such as the western US and India, where nearly all surface ozone concentration decreases due to historical land use changes are compensated by the increases caused by anthropogenic nitrogen deposition (0.3-1.5 ppbv over the western US and 0.5-2.3 ppbv over India).

\section{Conclusions}

In this study we present an exploratory study aiming to quantify the influences of anthropogenic nitrogen deposition on surface ozone air quality by using the GEOS-Chem chemical transport model asynchronously coupled with the CLM land model. Increased atmospheric nitrogen deposition from human activities can modulate plant growth and mineral nitrogen content in soil and further affect atmospheric composition through surface-atmosphere exchange processes. We consider here three processes including biogenic VOC emissions, ozone dry deposition, and soil $\mathrm{NO}_{x}$ emissions. A combination of GEOS-Chem and CLM allows us to investigate how these processes influence surface ozone and how anthropogenic nitrogen deposition perturbs them.

We simulate in GEOS-Chem global atmospheric nitrogen deposition fluxes for the present-day and the preindustrial (natural emissions only) conditions, and we then conduct near-equilibrium CLM simulations with these fluxes to estimate terrestrial vegetation $\mathrm{LAI}$, soil $\mathrm{NO}_{x}$ emissions, and their changes due to anthropogenic nitrogen deposition. The present-day (2006-2010) nitrogen deposition is estimated to be $114 \mathrm{Tg} \mathrm{Na}^{-1}$ with $57 \%\left(65 \mathrm{Tg} \mathrm{Na}^{-1}\right)$ deposited to the land, consistent with available measurements of wet deposition fluxes. Anthropogenic sources contribute $71 \%$ of the nitrogen deposition to the land on the global scale and 70$90 \%$ over the Northern Hemisphere continents. We find that anthropogenic nitrogen deposition leads to large-scale increases in LAI as well as soil $\mathrm{NO}_{x}$ emissions over the globe. The contributions from anthropogenic nitrogen deposition are particularly high over North America, Europe, and East Asia, with local values of $5-30 \%$ for LAI and $20-70 \%$ for present-day soil $\mathrm{NO}_{x}$ emissions.

Surface ozone changes driven by anthropogenic nitrogen deposition are then identified in additional GEOS-Chem simulations with CLM-simulated LAI and soil $\mathrm{NO}_{x}$ emissions. We find that the LAI enhancement due to anthropogenic nitrogen deposition can increase biogenic VOC emissions (e.g., a 6.6 Tg increase in isoprene emissions) but can also lead to higher ozone dry deposition velocities (1-15\% increases over the Northern Hemisphere continents). Surface ozone changes due to the two processes are largely offset. Anthropogenic nitrogen deposition also leads to general increases in soil $\mathrm{NO}_{x}$ emissions that increase the seasonal mean surface ozone concentrations over the globe except for North China, where ozone production is found to be $\mathrm{NO}_{x}$ saturated. We find that the net effects of anthropogenic nitrogen deposition lead to summer mean surface ozone increases of 1 ppbv over the southwestern US and 2 ppbv over India and north-central China, while leading to decreases of $0.5 \mathrm{ppbv}$ in the eastern US, and 1 ppbv over North China and western Europe.

To assess the importance of deposited anthropogenic nitrogen influences, we also estimate surface ozone changes driven by the past 20-year climate change (from 1986-1990 to 2006-2010) and historical land use change (from 1860 to 2000). The 20-year climate change has led to large changes in the seasonal mean surface ozone concentration $( \pm 10 \mathrm{ppbv})$, mainly driven by changes in temperature and other meteorological variables, while the historical land use change induces decreases of summer mean surface ozone by up to 57 ppbv in the Northern Hemisphere due to deforestation and cropland expansion as discussed in recent studies (Fu and Tai, 2015; Heald and Geddes, 2016). Compared with those changes, we find that the influences of anthropogenic nitrogen deposition can be comparable at regional scales. In particular, they may largely offset the surface ozone reduction 
due to historical land use change over the Northern Hemisphere continents.

While our study points out that anthropogenic nitrogen deposition can be important in modulating the surface ozone air quality, it should be acknowledged that considerable uncertainties still exist. The estimated surface ozone responses rely heavily on the parameterizations of surface-atmosphere exchange processes. Using different parameterizations with different meteorological data, large ranges have been found for the estimates of biogenic emissions (Guenther et al., 2012; Henrot et al., 2017), soil $\mathrm{NO}_{x}$ emissions (Hudman et al., 2012), and ozone dry deposition velocities (Hardacre et al., 2015). Future work is needed to reconcile them, especially in light of more observations of these emission and deposition fluxes, and understand the uncertainty ranges. The near-equilibrium CLM simulations applied in this study also imply that our estimates represent a long-term, steady-state impact and may represent quite different results from the transient responses to actual perturbations of the terrestrial nitrogen cycle over centurial timescales. In addition, previous studies have shown that nitrogen deposition can lead to a reduction of plant diversity (Sutton et al., 2014). This is not considered in our study since we use prescribed, constant PFT distributions, soil types, and soil $\mathrm{pH}$. All the possible uncertainties reflect the complexity in the biosphereatmosphere interactions and feedbacks and require future efforts for better characterizing these exchange processes in finer integrated models such as Earth system models.
Data availability. The datasets including measurements and model simulations can be accessed from websites listed in the references, downloaded from the webpage (http://www.phy.pku.edu.cn/ atmoscc/data/acp-2017-242-data.html, ACP-2017-242-suppdata, 2017), or accessed by contacting the corresponding author (Lin Zhang; zhanglg@pku.edu.cn). 


\section{Appendix A}

The section describes modifications we implemented to the CLM v4.5 model for better simulating the soil $\mathrm{NO}_{x}$ emissions and also reducing the model LAI overestimation. These include addition of soil $\mathrm{NO}_{x}$ emission and $\mathrm{NH}_{3}$ volatilization processes and an improved parameterization of nitrogen uptake by plants. We evaluate the CLM-simulated results with satellite LAI observations and soil $\mathrm{NO}_{x}$ emissions calculated by GEOS-Chem.

\section{A1 Soil NO $\mathrm{N}_{x}$ emissions}

The original CLM4.5 model does not estimate $\mathrm{NO}_{x}$ emissions from soil. Here we implement a process-based parameterization of soil $\mathrm{NO}_{x}$ emission as described by Parton et al. (2001). This parameterization has been recently applied to the land model LM3V-N (Huang et al., 2015). In the parameterization, soil $\mathrm{NO}_{x}$ from nitrification and denitrification is estimated based on the $\mathrm{NO}_{x}$ over $\mathrm{N}_{2} \mathrm{O}$ emission ratio, which varies with the gas diffusivity $\left(D / D_{0}\right)$ as described by the arctangent (ATAN) function (Parton et al., 2001).

$$
\begin{aligned}
& R_{\mathrm{NO}_{x}: \mathrm{N}_{2} \mathrm{O}}=15.2 \\
& \quad+\frac{35.4 \times \mathrm{ATAN}\left[0.68 \times \pi \times\left(10 \times \frac{D}{D_{0}}-1.86\right)\right]}{\pi}
\end{aligned}
$$

And the gas diffusivity is calculated as a function of air-filled porosity (AFPS; Davidson and Trumbore, 1995):

$$
\frac{D}{D_{0}}=0.209 \times \operatorname{AFPS}^{\frac{4}{3}}
$$

Above-soil $\mathrm{NO}_{x}$ emissions are thus derived from soil $\mathrm{N}_{2} \mathrm{O}$ emissions as already estimated in CLM4.5 and the $R_{\mathrm{NO}_{\mathrm{x}}: \mathrm{N}_{2} \mathrm{O}}$ ratios. However, we find that soil $\mathrm{NO}_{x}$ emissions derived from the original CLM and this parameterization show a distinctly different spatial pattern from those calculated in GEOS-Chem with the scheme of Hudman et al. (2012) (Fig. S1). To improve the consistency, we also add the process of $\mathrm{NH}_{3}$ volatilization and update the parameterization of plant nitrogen uptake in the model as described in the sections below. In addition, we have implemented a soil temperature $\left(T_{\text {soil }}\right)$ dependent factor (the equation below) from $\mathrm{Xu}$ and Prentice (2008) to the $\mathrm{N}_{2} \mathrm{O}$ and $\mathrm{N}_{2}$ emission ratio to reduce the CLM high soil $\mathrm{NO}_{x}$ emissions at high latitudes.

$$
f\left(T_{\text {soil }}\right)=\exp \left(308.56 \times\left(\frac{1}{68.02}-\frac{1}{T_{\text {soil }}+46.02}\right)\right)
$$

we implement a process-based $\mathrm{NH}_{3}$ volatilization parameterization in CLM following $\mathrm{Xu}$ and Prentice (2008). $\mathrm{NH}_{3}$ volatilization from soil $\left(\mathrm{V} \_\mathrm{NH}_{3}\right)$ is estimated as a function of water-filled pore space (WFPS), soil $\mathrm{pH}$, and temperature $\left(T_{\text {soil }}\right)$ given below.

V_NH $3=f(\mathrm{pH}) f\left(T_{\text {soil }}\right)(1-$ WFPS $) \frac{N_{\mathrm{NH}_{4}^{+}}}{b_{\mathrm{NH}_{4}^{+}}}$,

where $N_{\mathrm{NH}_{4}^{+}}$is the soil $\mathrm{NH}_{4}^{+}$content and $b_{\mathrm{NH}_{4}^{+}}$is the buffer parameter for $\mathrm{NH}_{4}^{+}$(10 as given by Huang et al., 2015). The soil $\mathrm{pH}$ factor $f(\mathrm{pH})$ and soil temperature factor $f\left(T_{\text {soil }}\right)$ are given below:

$$
\begin{aligned}
& f(\mathrm{pH})=e^{2 \times(\mathrm{pH}-10)}, \\
& f\left(T_{\text {soil }}\right)=\min \left(1, e^{308.56 \times\left(\frac{1}{71.02}-\frac{1}{T_{\text {soil }}+46.02}\right)}\right) .
\end{aligned}
$$

This $\mathrm{NH}_{3}$ volatilization parameterization corrects the CLM bias in the soil $\mathrm{NH}_{4}^{+}$concentration over desert areas and shows consistent results with $\mathrm{Xu}$ and Prentice (2008).

\section{A3 Plant nitrogen uptake}

In the original CLM4.5, nitrogen uptake by plants is estimated as plant demand as long as there is sufficient nitrogen supply. However, many factors may influence plant nitrogen uptake, such as soil inorganic nitrogen concentration, the fine-root mass, and soil temperature. Here we follow Thomas et al. (2013) and calculate in CLM the plant nitrogen uptake capacity $\left(U_{\mathrm{n}, \text { plant }}\right)$ based on the Hanes-Woolf mechanism:

$U_{\text {n,plant }}=V_{\text {n, max }} \frac{\mathrm{NH}_{4, \text { av }}+\mathrm{NO}_{3, \text { av }}}{\left(\mathrm{NH}_{4, \text { av }}+\mathrm{NO}_{3, \text { av }}\right)+K_{\text {min }}} C_{\text {root }} f\left(T_{\text {soil }}\right)$,

where $V_{\mathrm{n}, \max }=2.7 \times 10^{-8} \mathrm{~g} \mathrm{~N} \mathrm{~g} \mathrm{C}^{-1} \mathrm{~s}^{-1}$ is the maximum $\mathrm{N}$ uptake per unit fine-root $\mathrm{C}$ at $25^{\circ} \mathrm{C}, \mathrm{NH}_{4}$,av and $\mathrm{NO}_{3}$, av are the available mineral $\mathrm{NH}_{4}^{+}$and $\mathrm{NO}_{3}^{-}$in the soil, $K_{\min }=$ $0.83 \mathrm{~g} \mathrm{~N} \mathrm{~m}^{-2}$ is the half-saturation concentration of fine-root nitrogen uptake from Kronzucker et al. $(1995,1996), C_{\text {root }}$ is the fine-root carbon concentration $\left(\mathrm{g} \mathrm{C} \mathrm{m}^{-2}\right)$, and $f\left(T_{\text {soil }}\right)$ represents a function of limitation of soil temperature on plant nitrogen uptake as described in Thomas et al. (2013). The calculated uptake capacity is then compared to the plant demand, and the smaller one defines the plant uptake of mineral nitrogen in the modified CLM.

\section{A2 $\mathrm{NH}_{3}$ volatilization}

$\mathrm{NH}_{3}$ is highly volatile under high soil temperature and $\mathrm{pH}$ conditions. The original CLM calculates abnormally high soil $\mathrm{NH}_{4}^{+}$content over deserts (e.g., more than $20 \mathrm{~g} \mathrm{~N} \mathrm{~m}^{-2}$ in Sahara) due to a lack of the $\mathrm{NH}_{3}$ volatilization process. Here 


\section{The Supplement related to this article is available online at https://doi.org/10.5194/acp-17-9781-2017-supplement.}

Competing interests. The authors declare that they have no conflict of interest.

Acknowledgements. This work was supported by the National Key R\&D Program of China (2017YFC0210102), China's National Basic Research Program (2014CB441303), and the National Natural Science Foundation of China (41205103, 41475112, and 41405144). The collaboration was also supported by the General Research Fund (project no. 14323116, given to Amos P. K. Tai) of the Research Grants Council of Hong Kong.

Edited by: Hang Su

Reviewed by: two anonymous referees

\section{References}

Acid Deposition Monitoring Network in East Asia (EANET), available at: http://www.eanet.asia/index.html (last access: December 2015), 2015.

ACP-2017-242-suppdata, available at: http://www.phy.pku.edu.cn/ acaq/data/acp-2017-242-data.html (last access: August 2017), 2017

Ainsworth, E. A., Yendrek, C. R., Sitch, S., Collins, W. J., and Emberson, L. D.: The effects of tropospheric ozone on net primary productivity and implications for climate change, Ann. Rev. Plant Biol., 63, 637-661, 2012.

Amos, H. M., Jacob, D. J., Holmes, C. D., Fisher, J. A., Wang, Q., Yantosca, R. M., Corbitt, E. S., Galarneau, E., Rutter, A. P., Gustin, M. S., Steffen, A., Schauer, J. J., Graydon, J. A., Louis, V. L. St., Talbot, R. W., Edgerton, E. S., Zhang, Y., and Sunderland, E. M.: Gas-particle partitioning of atmospheric $\mathrm{Hg}(\mathrm{II})$ and its effect on global mercury deposition, Atmos. Chem. Phys., 12, 591-603, https://doi.org/10.5194/acp-12-591-2012, 2012.

Avnery, S., Mauzerall, D. L., Liu, J., and Horowitz, L. W.: Global crop yield reductions due to surface ozone exposure: 1. Year 2000 crop production losses and economic damage, Atmos. Environ., 45, 2284-2296, 2011.

Bala, G., Devaraju, N., Chaturvedi, R. K., Caldeira, K., and Nemani, R.: Nitrogen deposition: how important is it for global terrestrial carbon uptake?, Biogeosciences, 10, 71477160, https://doi.org/10.5194/bg-10-7147-2013, 2013.

Baron, J. S., Barber, M., Adams, M., Agboola, J. I., Allen, E. B., Bealey, W. J., Bobbink, R., Bobrovsky, M. V., Bowman, W. D., Branquinho, C., Bustamente, M. M. C., Clark, C. M., Cocking, E. C., Cruz, C., Davidson, E., Denmead, O. T., Dias, T., Dise, N. B., Feest, A., Galloway, J. N., Geiser, L. H., Gilliam, F. S., Harrison, I. J., Khanina, L. G., Lu, X., Manrique, E., Hueso, R. O., Ometto, J. P. H. B., Payne, R., Scheuschner, T., Sheppard, L. J., Simpson, G. L., Singh, Y. V., Stevens, C. J., Strachan, I., Sverdrup, H., Tokuchi, N., Dobben, H. v., and Woodin, S.: The Effects of Atmospheric Nitrogen Deposition on Terrestrial and
Freshwater Biodiversity, in: Nitrogen Deposition, Critical Loads and Biodiversity, edited by: Sutton, M. A., Mason, K. E., Sheppard, L. J., Sverdrup, H., Haeuber, R., and Hicks, W. K., Springer Netherlands, Dordrecht, 465-480, 2014.

Bates, D. V.: Ambient Ozone and Mortality, Epidemiology, 16, 427-429, https://doi.org/10.1097/01.ede.0000165793.71278.ec, 2005.

Camalier, L., Cox, W., and Dolwick, P.: The effects of meteorology on ozone in urban areas and their use in assessing ozone trends, Atmos. Environ., 41, 7127-7137, 2007.

Climatic Research Unit (CRU)-National Centers for Environmental Prediction (NCEP) (CRUNCEP), available at: http://dods.extra cea.fr/store/p529viov/cruncep/V4_1901_2011/ (last access: December 2015), 2015.

Community Earth System Model (CESM) input data repository, available at: https://svn-ccsm-inputdata.cgd.ucar.edu/trunk/ inputdata/ (last access: December 2015), 2015.

Dahlin, K. M., Fisher, R. A., and Lawrence, P. J.: Environmental drivers of drought deciduous phenology in the Community Land Model, Biogeosciences, 12, 5061-5074, https://doi.org/10.5194/bg-12-5061-2015, 2015.

Davidson, E. A. and Trumbore, S. E.: Gas diffusivity and production of $\mathrm{CO}_{2}$ in deep soils of the eastern Amazon, Tellus B, 47, 550565, https://doi.org/10.1034/j.1600-0889.47.issue5.3.x, 1995.

Del Grosso, S. J., Parton, W. J., Mosier, A. R., Ojima, D. S., Kulmala, A. E., and Phongpan, S.: General model for $\mathrm{N}_{2} \mathrm{O}$ and $\mathrm{N}_{2}$ gas emissions from soils due to dentrification, Global Biogeochem. Cy., 14, 1045-1060, https://doi.org/10.1029/1999GB001225, 2000.

Dentener, F., Drevet, J., Lamarque, J. F., Bey, I., Eickhout, B., Fiore, A. M., Hauglustaine, D., Horowitz, L. W., Krol, M., Kulshrestha, U. C., Lawrence, M., Galy-Lacaux, C., Rast, S., Shindell, D., Stevenson, D., Van Noije, T., Atherton, C., Bell, N., Bergman, D., Butler, T., Cofala, J., Collins, B., Doherty, R., Ellingsen, K., Galloway, J., Gauss, M., Montanaro, V., Müller, J. F., Pitari, G., Rodriguez, J., Sanderson, M., Solmon, F., Strahan, S., Schultz, M., Sudo, K., Szopa, S., and Wild, O.: Nitrogen and sulfur deposition on regional and global scales: A multimodel evaluation, Global Biogeochem. Cy., 20, GB4003, https://doi.org/10.1029/2005GB002672, 2006.

Doherty, R. M., Wild, O., Shindell, D. T., Zeng, G., MacKenzie, I. A., Collins, W. J., Fiore, A. M., Stevenson, D. S., Dentener, F. J., Schultz, M. G., Hess, P., Derwent, R. G., and Keating, T. J.: Impacts of climate change on surface ozone and intercontinental ozone pollution: A multi-model study, J. Geophys. Res.-Atmos, 118, 3744-3763, https://doi.org/10.1002/jgrd.50266, 2013.

Duarte, H. F., Raczka, B. M., Ricciuto, D. M., Lin, J. C., Koven, C. D., Thornton, P. E., Bowling, D. R., Lai, C.-T., Bible, K. J., and Ehleringer, J. R.: Evaluating the Community Land Model (CLM 4.5) at a Coniferous Forest Site in Northwestern United States Using Flux and Carbon-Isotope Measurements, Biogeosciences Discuss., https://doi.org/10.5194/bg-2016-441, in review, 2016.

Duce, R. A., LaRoche, J., Altieri, K., Arrigo, K. R., Baker, A. R., Capone, D. G., Cornell, S., Dentener, F., Galloway, J., Ganeshram, R. S., Geider, R. J., Jickells, T., Kuypers, M. M., Langlois, R., Liss, P. S., Liu, S. M., Middelburg, J. J., Moore, C. M., Nickovic, S., Oschlies, A., Pedersen, T., Prospero, J., Schlitzer, R., Seitzinger, S., Sorensen, L. L., Uematsu, M., Ulloa, O., Voss, M., Ward, B., and Zamora, L.: Impacts of Atmospheric 
Anthropogenic Nitrogen on the Open Ocean, Science, 320, 893897, https://doi.org/10.1126/science.1150369, 2008.

Ellis, R. A., Jacob, D. J., Sulprizio, M. P., Zhang, L., Holmes, C. D., Schichtel, B. A., Blett, T., Porter, E., Pardo, L. H., and Lynch, J. A.: Present and future nitrogen deposition to national parks in the United States: critical load exceedances, Atmos. Chem. Phys., 13, 9083-9095, https://doi.org/10.5194/acp13-9083-2013, 2013.

European Monitoring and Evaluation Program (EMEP), available at: http://www.nilu.no/projects/ccc/emepdata.html (last access: December 2015), 2015.

Fowler, D., Pilegaard, K., Sutton, M. A., Ambus, P., Raivonen, M., Duyzer, J., Simpson, D., Fagerli, H., Fuzzi, S., Schjoerring, J. K., Granier, C., Neftel, A., Isaksen, I. S. A., Laj, P., Maione, M., Monks, P. S., Burkhardt, J., Daemmgen, U., Neirynck, J., Personne, E., Wichink-Kruit, R., Butterbach-Bahl, K., Flechard, C., Tuovinen, J. P., Coyle, M., Gerosa, G., Loubet, B., Altimir, N., Gruenhage, L., Ammann, C., Cieslik, S., Paoletti, E., Mikkelsen, T. N., Ro-Poulsen, H., Cellier, P., Cape, J. N., Horváth, L., Loreto, F., Niinemets, Ü., Palmer, P. I., Rinne, J., Misztal, P., Nemitz, E., Nilsson, D., Pryor, S., Gallagher, M. W., Vesala, T., Skiba, U., Brüggemann, N., Zechmeister-Boltenstern, S., Williams, J., O'Dowd, C., Facchini, M. C., de Leeuw, G., Flossman, A., Chaumerliac, N., and Erisman, J. W.: Atmospheric composition change: Ecosystems-Atmosphere interactions, Atmos. Environ., 43, 5193-5267, 2009.

Fowler, D., Coyle, M., Skiba, U., Sutton, M. A., Cape, J. N., Reis, S., Sheppard, L. J., Jenkins, A., Grizzetti, B., Galloway, J. N., Vitousek, P., Leach, A., Bouwman, A. F., Butterbach-Bahl, K., Dentener, F., Stevenson, D., Amann, M., and Voss, M.: The global nitrogen cycle in the twenty-first century, Philos. T. Roy. Soc. B, 368, 2621, https://doi.org/10.1098/rstb.2013.0164, 2013.

Fu, T.-M., Zheng, Y., Paulot, F., Mao, J., and Yantosca, R. M.: Positive but variable sensitivity of August surface ozone to large-scale warming in the southeast United States, Nature Clim. Change, 5, 454-458, https://doi.org/10.1038/nclimate2567, 2015.

Fu, Y. and Tai, A. P. K.: Impact of climate and land cover changes on tropospheric ozone air quality and public health in East Asia between 1980 and 2010, Atmos. Chem. Phys., 15, 10093-10106, https://doi.org/10.5194/acp-15-10093-2015, 2015.

Fu, Y., Tai, A. P. K., and Liao, H.: Impacts of historical climate and land cover changes on fine particulate matter $\left(\mathrm{PM}_{2.5}\right)$ air quality in East Asia between 1980 and 2010, Atmos. Chem. Phys., 16, 10369-10383, https://doi.org/10.5194/acp-16-103692016, 2016.

Galloway, J. N., Dentener, F. J., Capone, D. G., Boyer, E. W., Howarth, R. W., Seitzinger, S. P., Asner, G. P., Cleveland, C. C., Green, P. A., Holland, E. A., Karl, D. M., Michaels, A. F., Porter, J. H., Townsend, A. R., and Vöosmarty, C. J.: Nitrogen Cycles: Past, Present, and Future, Biogeochemistry, 70, 153-226, https://doi.org/10.1007/s10533-004-0370-0, 2004.

Geddes, J. A., Heald, C. L., Silva, S. J., and Martin, R. V.: Land cover change impacts on atmospheric chemistry: simulating projected large-scale tree mortality in the United States, Atmos. Chem. Phys., 16, 2323-2340, https://doi.org/10.5194/acp-162323-2016, 2016.

Guenther, A. B., Jiang, X., Heald, C. L., Sakulyanontvittaya, T., Duhl, T., Emmons, L. K., and Wang, X.: The Model of
Emissions of Gases and Aerosols from Nature version 2.1 (MEGAN2.1): an extended and updated framework for modeling biogenic emissions, Geosci. Model Dev., 5, 1471-1492, https://doi.org/10.5194/gmd-5-1471-2012, 2012.

Hardacre, C., Wild, O., and Emberson, L.: An evaluation of ozone dry deposition in global scale chemistry climate models, Atmos. Chem. Phys., 15, 6419-6436, https://doi.org/10.5194/acp15-6419-2015, 2015.

Heald, C. L. and Geddes, J. A.: The impact of historical land use change from 1850 to 2000 on secondary particulate matter and ozone, Atmos. Chem. Phys., 16, 14997-15010, https://doi.org/10.5194/acp-16-14997-2016, 2016.

Henrot, A.-J., Stanelle, T., Schröder, S., Siegenthaler, C., Taraborrelli, D., and Schultz, M. G.: Implementation of the MEGAN (v2.1) biogenic emission model in the ECHAM6-HAMMOZ chemistry climate model, Geosci. Model Dev., 10, 903-926, https://doi.org/10.5194/gmd-10-903-2017, 2017.

Huang, Y. and Gerber, S.: Global soil nitrous oxide emissions in a dynamic carbon-nitrogen model, Biogeosciences, 12, 64056427, https://doi.org/10.5194/bg-12-6405-2015, 2015.

Hudman, R. C., Moore, N. E., Mebust, A. K., Martin, R. V., Russell, A. R., Valin, L. C., and Cohen, R. C.: Steps towards a mechanistic model of global soil nitric oxide emissions: implementation and space based-constraints, Atmos. Chem. Phys., 12, 7779-7795, https://doi.org/10.5194/acp-12-7779-2012, 2012.

Jacob, D. J. and Winner, D. A.: Effect of climate change on air quality, Atmos. Environ., 43, 51-63, 2009.

Jerrett, M., Burnett, R. T., Pope, C. A. I., Ito, K., Thurston, G., Krewski, D., Shi, Y., Calle, E., and Thun, M.: Long-Term Ozone Exposure and Mortality, New England Journal of Medicine, 360, 1085-1095, 2009.

Jones, C., Lowe, J., Liddicoat, S., and Betts, R.: Committed terrestrial ecosystem changes due to climate change, Nature Geosci., 2, 484-487, https://doi.org/10.1038/ngeo555, 2009.

Koven, C. D., Riley, W. J., Subin, Z. M., Tang, J. Y., Torn, M. S., Collins, W. D., Bonan, G. B., Lawrence, D. M., and Swenson, S. C.: The effect of vertically resolved soil biogeochemistry and alternate soil $\mathrm{C}$ and $\mathrm{N}$ models on $\mathrm{C}$ dynamics of CLM4, Biogeosciences, 10, 7109-7131, https://doi.org/10.5194/bg-107109-2013, 2013.

Kronzucker, H. J., Siddiqi, M. Y., and Glass, A.: Kinetics of $\mathrm{NO}_{3}$-Influx in Spruce, Plant Physiol., 109, 319-326, https://doi.org/10.1104/pp.109.1.319, 1995.

Kronzucker, H. J., Siddiqi, M. Y., and Glass, A.: Kinetics of NH4+ Influx in Spruce, Plant Physiol., 110, 773-779, https://doi.org/10.1104/pp.110.3.773, 1996.

Kurokawa, J., Ohara, T., Morikawa, T., Hanayama, S., JanssensMaenhout, G., Fukui, T., Kawashima, K., and Akimoto, H.: Emissions of air pollutants and greenhouse gases over Asian regions during 2000-2008: Regional Emission inventory in ASia (REAS) version 2, Atmos. Chem. Phys., 13, 11019-11058, https://doi.org/10.5194/acp-13-11019-2013, 2013.

Lamarque, J.-F., Dentener, F., McConnell, J., Ro, C.-U., Shaw, M., Vet, R., Bergmann, D., Cameron-Smith, P., Dalsoren, S., Doherty, R., Faluvegi, G., Ghan, S. J., Josse, B., Lee, Y. H., MacKenzie, I. A., Plummer, D., Shindell, D. T., Skeie, R. B., Stevenson, D. S., Strode, S., Zeng, G., Curran, M., Dahl-Jensen, D., Das, S., Fritzsche, D., and Nolan, M.: Multi-model mean nitrogen and sulfur deposition from the Atmospheric Chem- 
istry and Climate Model Intercomparison Project (ACCMIP): evaluation of historical and projected future changes, Atmos. Chem. Phys., 13, 7997-8018, https://doi.org/10.5194/acp-137997-2013, 2013.

Lawrence, P. J. and Chase, T. N.: Representing a new MODIS consistent land surface in the Community Land Model (CLM 3.0), J. Geophys. Res.-Biogeo., 112, G01023, https://doi.org/10.1029/2006JG000168, 2007.

Liu, H., Jacob, D. J., Bey, I., and Yantosca, R. M.: Constraints from $210 \mathrm{~Pb}$ and $7 \mathrm{Be}$ on wet deposition and transport in a global threedimensional chemical tracer model driven by assimilated meteorological fields, J. Geophys. Res.-Atmos, 106, 12109-12128, https://doi.org/10.1029/2000JD900839, 2001.

Liu, L. and Greaver, T. L.: A review of nitrogen enrichment effects on three biogenic GHGs: the $\mathrm{CO}_{2}$ sink may be largely offset by stimulated $\mathrm{N}_{2} \mathrm{O}$ and $\mathrm{CH}_{4}$ emission, Ecol. Lett., 12, 1103-1117, 2009

Liu, X., Zhang, Y., Han, W., Tang, A., Shen, J., Cui, Z., Vitousek, P., Erisman, J. W., Goulding, K., Christie, P., Fangmeier, A., and Zhang, F.: Enhanced nitrogen deposition over China, Nature, 494, 459-462, https://doi.org/10.1038/nature11917, 2013.

Lu, X., Mao, Q., Gilliam, F. S., Luo, Y., and Mo, J.: Nitrogen deposition contributes to soil acidification in tropical ecosystems, Glob. Change Biol., 20, 3790-3801, 2014.

Mao, J., Jacob, D. J., Evans, M. J., Olson, J. R., Ren, X., Brune, W. H., Clair, J. M. St., Crounse, J. D., Spencer, K. M., Beaver, M. R., Wennberg, P. O., Cubison, M. J., Jimenez, J. L., Fried, A., Weibring, P., Walega, J. G., Hall, S. R., Weinheimer, A. J., Cohen, R. C., Chen, G., Crawford, J. H., McNaughton, C., Clarke, A. D., Jaeglé, L., Fisher, J. A., Yantosca, R. M., Le Sager, P., and Carouge, C.: Chemistry of hydrogen oxide radicals $\left(\mathrm{HO}_{x}\right)$ in the Arctic troposphere in spring, Atmos. Chem. Phys., 10, 58235838, https://doi.org/10.5194/acp-10-5823-2010, 2010.

Mari, C., Jacob, D. J., and Bechtold, P.: Transport and scavenging of soluble gases in a deep convective cloud, J. Geophys. Res.-Atmos, 105, 22255-22267, https://doi.org/10.1029/2000JD900211, 2000.

Matyssek, R., Karnosky, D. F., Wieser, G., Percy, K., Oksanen, E., Grams, T. E. E., Kubiske, M., Hanke, D., and Pretzsch, H.: Advances in understanding ozone impact on forest trees: Messages from novel phytotron and free-air fumigation studies, Environ. Pollut., 158, 1990-2006, 2010.

Mills, G., Buse, A., Gimeno, B., Bermejo, V., Holland, M., Emberson, L., and Pleijel, H.: A synthesis of AOT40-based response functions and critical levels of ozone for agricultural and horticultural crops, Atmos. Environ., 41, 2630-2643, 2007.

Murray, L. T., Jacob, D. J., Logan, J. A., Hudman, R. C., and Koshak, W. J.: Optimized regional and interannual variability of lightning in a global chemical transport model constrained by LIS/OTD satellite data, J. Geophys. Res.-Atmos., 117, D20307 https://doi.org/10.1029/2012JD017934, 2012.

National Acid Deposition Program (NADP), available at: http:// nadp.sws.uiuc.edu/ (last access: December 2015), 2015.

Oleson, K. W., Lawrence, D. M., Bonan, G. B., Drewniak, B., Huang, M., Koven, C. D., Levis, S., Li, F., Riley, W. J., Subin, Z. M., Swenson, S. C., Thornton, P. E., Bozbiyik, A., Fisher, R., Heald, C. L., Kluzek, E., Lamarque, J.-F., Lawrence, P. J., Leung, L. R., Lipscomb, W., Muszala, S., Ricciuto, D. M., Sacks, W., Sun, Y., Tang, J., and Yang, Z.-L.: Technical Description of ver- sion 4.5 of the Community Land Model (CLM). Ncar Technical Note NCAR/TN-503+STR, National Center for Atmospheric Research, 422 pp., https://doi.org/10.5065/D6RR1W7M, 2013.

Pan, Y. P., Wang, Y. S., Tang, G. Q., and Wu, D.: Wet and dry deposition of atmospheric nitrogen at ten sites in Northern China, Atmos. Chem. Phys., 12, 6515-6535, https://doi.org/10.5194/acp12-6515-2012, 2012.

Park, R. J., Jacob, D. J., Field, B. D., Yantosca, R. M., and Chin, M.: Natural and transboundary pollution influences on sulfate-nitrate-ammonium aerosols in the United States: Implications for policy, J. Geophys. Res.-Atmos., 109, D15204, https://doi.org/10.1029/2003JD004473, 2004.

Parton, W. J., Holland, E. A., Del Grosso, S. J., Hartman, M. D., Martin, R. E., Mosier, A. R., Ojima, D. S., and Schimel, D. S.: Generalized model for $\mathrm{NO} x$ and $\mathrm{N}_{2} \mathrm{O}$ emissions from soils, J. Geophys. Res.-Atmos., 106, 17403-17419, https://doi.org/10.1029/2001JD900101, 2001.

Pickering, K. E., Wang, Y., Tao, W.-K., Price, C., and Müller, J.F.: Vertical distributions of lightning NOx for use in regional and global chemical transport models, J. Geophys. Res.-Atmos., 103, 31203-31216, https://doi.org/10.1029/98JD02651, 1998.

Price, C. and Rind, D.: A simple lightning parameterization for calculating global lightning distributions, J. Geophys. Res.-Atmos., 97, 9919-9933, https://doi.org/10.1029/92JD00719, 1992.

Qian, T., Dai, A., Trenberth, K. E., and Oleson, K. W.: Simulation of Global Land Surface Conditions from 1948 to 2004. Part I: Forcing Data and Evaluations, J. Hydrometeorol., 7, 953-975, 2006.

Rodríguez, L. and Macías, F.: Eutrophication trends in forest soils in Galicia (NW Spain) caused by the atmospheric deposition of nitrogen compounds, Chemosphere, 63, 1598-1609, 2006.

Sadiq, M., Tai, A. P. K., Lombardozzi, D., and Val Martin, M.: Effects of ozone-vegetation coupling on surface ozone air quality via biogeochemical and meteorological feedbacks, Atmos. Chem. Phys., 17, 3055-3066, https://doi.org/10.5194/acp-173055-2017, 2017.

Sauvage, B., Martin, R. V., van Donkelaar, A., Liu, X., Chance, K., Jaeglé, L., Palmer, P. I., Wu, S., and Fu, T.-M.: Remote sensed and in situ constraints on processes affecting tropical tropospheric ozone, Atmos. Chem. Phys., 7, 815-838, https://doi.org/10.5194/acp-7-815-2007, 2007.

Stevens, C. J., Maskell, L. C., Smart, S. M., Caporn, S. J. M., Dise, N. B., and Gowing, D. J. G.: Identifying indicators of atmospheric nitrogen deposition impacts in acid grasslands, Biol. Conserv., 142, 2069-2075, 2009.

Su, H., Cheng, Y., Oswald, R., Behrendt, T., Trebs, I., Meixner, F. X., Andreae, M. O., Cheng, P., Zhang, Y., and Pöschl, U.: Soil Nitrite as a Source of Atmospheric HONO and OH Radicals, Science, 333, 1616-1618, https://doi.org/10.1126/science.1207687, 2011.

Sutton, M. A., Mason, K. E., Sheppard, L. J., Sverdrup, H., Haeuber, R., and Hicks, W. K.: Nitrogen deposition, critical loads and biodiversity, Springer Science \& Business Media, 535 pp., 2014.

Tai, A. P. K., Martin, M. V., and Heald, C. L.: Threat to future global food security from climate change and ozone air pollution, Nature Clim. Change, 4, 817-821, https://doi.org/10.1038/nclimate2317, 2014.

Tang, G., Wang, Y., Li, X., Ji, D., Hsu, S., and Gao, X.: Spatialtemporal variations in surface ozone in Northern China as ob- 
served during 2009-2010 and possible implications for future air quality control strategies, Atmos. Chem. Phys., 12, 2757-2776, https://doi.org/10.5194/acp-12-2757-2012, 2012.

Thomas, R. Q., Bonan, G. B., and Goodale, C. L.: Insights into mechanisms governing forest carbon response to nitrogen deposition: a model-data comparison using observed responses to nitrogen addition, Biogeosciences, 10, 3869-3887, https://doi.org/10.5194/bg-10-3869-2013, 2013.

Val Martin, M., Heald, C. L., Lamarque, J.-F., Tilmes, S., Emmons, L. K., and Schichtel, B. A.: How emissions, climate, and land use change will impact mid-century air quality over the United States: a focus on effects at national parks, Atmos. Chem. Phys., 15, 2805-2823, https://doi.org/10.5194/acp15-2805-2015, 2015.

van der Werf, G. R., Randerson, J. T., Giglio, L., Collatz, G. J., Mu, M., Kasibhatla, P. S., Morton, D. C., DeFries, R. S., Jin, Y., and van Leeuwen, T. T.: Global fire emissions and the contribution of deforestation, savanna, forest, agricultural, and peat fires (1997-2009), Atmos. Chem. Phys., 10, 11707-11735, https://doi.org/10.5194/acp-10-11707-2010, 2010.

Vestreng, V. and Klein, H.: Emission data reported to UNECE/EMEP: Quality assurance and trend analysis \& Presentation of WebDab, Det norske meterologiske institutt, 2002.

Vet, R., Artz, R. S., Carou, S., Shaw, M., Ro, C.-U., Aas, W., Baker, A., Bowersox, V. C., Dentener, F., Galy-Lacaux, C., Hou, A., Pienaar, J. J., Gillett, R., Forti, M. C., Gromov, S., Hara, H., Khodzher, T., Mahowald, N. M., Nickovic, S., Rao, P. S. P., and Reid, N. W.: A global assessment of precipitation chemistry and deposition of sulfur, nitrogen, sea salt, base cations, organic acids, acidity and pH, and phosphorus, Atmos. Environ., 93, $3-$ 100, 2014.

Wesely, M. L.: Parameterization of surface resistances to gaseous dry deposition in regional-scale numerical models, Atmos. Environ., 23, 1293-1304, 1989.

$\mathrm{Xu}, \mathrm{R}$. I. and Prentice, I. C.: Terrestrial nitrogen cycle simulation with a dynamic global vegetation model, Glob. Change Biol., 14, 1745-1764, https://doi.org/10.1111/j.1365-2486.2008.01625.x, 2008.

Young, P. J., Archibald, A. T., Bowman, K. W., Lamarque, J.-F., Naik, V., Stevenson, D. S., Tilmes, S., Voulgarakis, A., Wild, O., Bergmann, D., Cameron-Smith, P., Cionni, I., Collins, W. J., Dalsøren, S. B., Doherty, R. M., Eyring, V., Faluvegi, G., Horowitz, L. W., Josse, B., Lee, Y. H., MacKenzie, I. A., Nagashima, T., Plummer, D. A., Righi, M., Rumbold, S. T., Skeie, R. B., Shindell, D. T., Strode, S. A., Sudo, K., Szopa, S., and Zeng, G.: Preindustrial to end 21 st century projections of tropospheric ozone from the Atmospheric Chemistry and Climate Model Intercomparison Project (ACCMIP), Atmos. Chem. Phys., 13, 20632090, https://doi.org/10.5194/acp-13-2063-2013, 2013.
Yue, X. and Unger, N.: Ozone vegetation damage effects on gross primary productivity in the United States, Atmos. Chem. Phys., 14, 9137-9153, https://doi.org/10.5194/acp-149137-2014, 2014.

Yue, X., Mickley, L. J., Logan, J. A., Hudman, R. C., Martin, M. V., and Yantosca, R. M.: Impact of 2050 climate change on North American wildfire: consequences for ozone air quality, Atmos. Chem. Phys., 15, 10033-10055, https://doi.org/10.5194/acp-1510033-2015, 2015.

Zaehle, S., Ciais, P., Friend, A. D., and Prieur, V.: Carbon benefits of anthropogenic reactive nitrogen offset by nitrous oxide emissions, Nature Geosci, 4, 601-605, https://doi.org/10.1038/ngeo1207, 2011.

Zhang, L., Gong, S., Padro, J., and Barrie, L.: A size-segregated particle dry depo- sition scheme for an atmospheric aerosol module, Atmos. Environ., 35, 549-560, 2001.

Zhang, L., Jacob, D. J., Downey, N. V., Wood, D. A., Blewitt, D., Carouge, C. C., van Donkelaar, A., Jones, D. B. A., Murray, L. T., and Wang, Y.: Improved estimate of the policy-relevant background ozone in the United States using the GEOS-Chem global model with $1 / 2^{\circ} \times 2 / 3^{\circ}$ horizontal resolution over North America, Atmos. Environ., 45, 6769-6776, 2011.

Zhang, L., Jacob, D. J., Knipping, E. M., Kumar, N., Munger, J. W., Carouge, C. C., van Donkelaar, A., Wang, Y. X., and Chen, D.: Nitrogen deposition to the United States: distribution, sources, and processes, Atmos. Chem. Phys., 12, 4539-4554, https://doi.org/10.5194/acp-12-4539-2012, 2012.

Zhang, L., Jacob, D. J., Yue, X., Downey, N. V., Wood, D. A., and Blewitt, D.: Sources contributing to background surface ozone in the US Intermountain West, Atmos. Chem. Phys., 14, 52955309, https://doi.org/10.5194/acp-14-5295-2014, 2014.

Zhang, Y., Cooper, O. R., Gaudel, A., Thompson, A. M., Nedelec, P., Ogino, S.-Y., and West, J. J.: Tropospheric ozone change from 1980 to 2010 dominated by equatorward redistribution of emissions, Nature Geosci., 9, 875-879, 2016.

Zhao, Y., Zhang, L., Pan, Y., Wang, Y., Paulot, F., and Henze, D. K.: Atmospheric nitrogen deposition to the northwestern Pacific: seasonal variation and source attribution, Atmos. Chem. Phys., 15, 10905-10924, https://doi.org/10.5194/acp-15-109052015, 2015.

Zhao, Y., Zhang, L., Chen, Y., Liu, X., Xu, W., Pan, Y., and Duan, L.: Atmospheric nitrogen deposition to China: A model analysis on nitrogen budget and critical load exceedance, Atmos. Environ., 153, 32-40, 2017. 